\title{
A Systematic Review of Heavy Metals of Anthropogenic Origin in Environmental Media and Biota in the Context of Gold Mining in Ghana
}

\author{
Frederick Ato Armah, ${ }^{1,2}$ Reginald Quansah, ${ }^{3}$ and Isaac Luginaah ${ }^{4}$ \\ ${ }^{1}$ Environmental Health and Hazards Laboratory, Department of Geography, Western University, 1151 Richmond Street, \\ ON, Canada N6A 5C2 \\ ${ }^{2}$ Department of Environmental Science, School of Biological Sciences, University of Cape Coast, Cape Coast, Ghana \\ ${ }^{3}$ Biological, Environmental \& Occupational Health Sciences, School of Public Health, University of Ghana, Legon, Accra, Ghana \\ ${ }^{4}$ Department of Geography, Western University, 1151 Richmond Street, ON, Canada N6A 5C2
}

Correspondence should be addressed to Frederick Ato Armah; farmah@ucc.edu.gh

Received 16 June 2014; Accepted 10 July 2014; Published 9 November 2014

Academic Editor: Constantine Stalikas

Copyright (C) 2014 Frederick Ato Armah et al. This is an open access article distributed under the Creative Commons Attribution License, which permits unrestricted use, distribution, and reproduction in any medium, provided the original work is properly cited.

\begin{abstract}
Heavy metal accumulation in the food chain is an issue of global concern because it eventually leads to toxic effects on humans through the water we drink, contaminated soils, crops, and animals. Reports of toxicant levels in environmental media (air, water, and soil) and biota in Ghana were sought in SCOPUS, PubMed, MEDLINE, and EMBASE. Of 1004 bibliographic records identified, 54 studies were included in evidence synthesis. A disproportionately large number of papers (about 80\%) focused exclusively on environmental media. Papers focusing on biomonitoring and human health were relatively few. Studies reported a high degree of spatial variability for the concentrations of 8 metals in groundwater. Generally, heavy metal concentrations in soil reported by the studies reviewed were higher than metal concentrations in riverine sediments. Urine and hair were the most common biological markers of heavy metal exposure used by the studies reviewed unlike nails, which were sparingly used. By and large, published results on the levels of heavy metals in goldmine and non-mine workers yielded contradictory results. Mostly, concentrations of heavy metals reported by the studies reviewed for nails were higher than for hair. A high degree of variability in the heavy metal concentrations in human subjects in the studies reviewed is likely due to heterogeneity in physiological states, excretion profiles, and body burdens of individuals. These, in turn, may be a product of genetic polymorphisms influencing detoxification efficiency.
\end{abstract}

\section{Introduction}

Over the past three decades, the term "heavy metals" has been widely used in the scientific literature on ecotoxicology. It is frequently considered as an assemblage name for metals and semimetals (metalloids) that have been linked with contamination and potential toxicity or ecotoxicity [1]. The term "heavy metals" has, however, been used inconsistently in the scientific literature. This has culminated in considerable misperception of the significance of the term. There is also a propensity to suppose that all the so-called "heavy metals" have highly toxic or ecotoxic properties [1]. According to Duffus [1], the scientifically sound designations of elements generally considered as heavy metals are as follows: As,
$\mathrm{Cd}, \mathrm{Hg}, \mathrm{Pb}$, and $\mathrm{Sb}$ (Chalcophile); $\mathrm{Fe}, \mathrm{Co}, \mathrm{Cu}, \mathrm{Ni}$, and $\mathrm{Zn}$ (lithophile/chalcophile); and Mn and Cr (lithophile). Despite some recognition that the term "heavy metals" is a misnomer, we resort to its use in this paper for two fundamental reasons. First, although the term "heavy metals" has been queried over many years, for example, by Phipps [2], and by Loon and Duffy [3], efforts to replace it by chemically sound terminology have so far failed. Secondly, all the papers systematically reviewed in this study specifically used the term "heavy metals."

Heavy metals in water, sediments, air, and other environmental media are of great environmental concern because of their potential long-term effects on human health 
particularly in developing countries where remedial techniques are nascent [4-8]. The origin of such metals in the natural environment is either geogenic or anthropogenic releases $[9,10]$. In general, the anthropogenic releases constitute a constant source of pollution, whereas surface runoff is a seasonal phenomenon which is influenced by climate within the environmental system. The concentrations of heavy metal (loid)s in soils and other environmental media can vary widely, even in uncontaminated environments. Noticeable dissimilarities in the geochemical composition of the rocks which constitute the parent materials of soils and disparities in the strength of soil-forming processes can lead to extensive ranges of total and available concentrations of most elements in soils, even in those unaffected by contamination [4]. Nevertheless, contamination from many sources can often give rise to some very high concentrations of heavy metal (loid)s [4] which can cause toxicity in soil organisms and susceptible plants, but this depends on the factors affecting the bioavailability of the elements [4]. Many investigations have been conducted on anthropogenic contaminants of ecosystems across the globe $[11,12]$.

In Ghana, which exemplifies a country where extensive research on heavy metals has hitherto been carried out because of its extensive mining industry, one of the main anthropogenic sources of concern is gold mining, both surface and underground. Gold mining is widespread and according to Naylor [13], it contributes about $44 \%$ of Ghana's export earnings. The large-scale extraction of gold occurs predominantly in the Western and Ashanti regions for example, Bibiani and Obuasi, and is accompanied by arsenic, mercury, and sulphur contamination to surface and groundwater bodies, soil and even air pollution causing acid rain and degradation to the surrounding environment and impacts on human health $[14,15]$. With the liberalization of the gold mining sector in the mid-1980s, gold mining-dependent livelihoods have soared, employing extraction methods that invariably release mercury into surrounding water sources $[5,16,17]$. In the past, gold mining was restricted to the south; lately however, exploration is increasing in the north, especiallyin the Upper East Region. Iron and manganese have also been found in elevated concentrations in water in Ghana [9]. This has culminated in the closure of hundreds of wells in favour of surface waters likely contaminated with harmful microorganisms [18]. Up till now, mining related studies in Ghana conducted on environmental samples (water, air, soil, sediment, etc.) and biota (fish, urine, blood, nails, etc.) include $\mathrm{Hg}[19,20]$, As $[14,15]$, Fe and $\mathrm{Mn}[9,21], \mathrm{Pb}[7,18]$, and $\mathrm{Cd}$ and $\mathrm{Cu}[5,16,17]$.

Despite the large body of literature that has been devoted to heavy metal pollution in Ghana, the results are mixed and are disparate making it quite difficult to elicit a coherent account on the scope and levels of heavy metal pollution in the environment and in biota, especially in humans, across Ghana. Consequently, this study aims to cumulate scientific evidence on heavy metal pollution in the environment and in biota in Ghana through synthesis of existing data. This systematic review was conducted for a variety of reasons, but it was not limited to the synthesis of evidence on the magnitude of heavy metal contamination or to supporting evidence-based policy or practice. This review provides useful information for designing future research on heavy metal pollution in Ghana and other jurisdictions. In particular, it will help to place future studies in context by describing what we knew before and what we hoped to learn from any future study on heavy metal pollution in Ghana and in other contexts.

\section{Materials and Methods}

2.1. Search Strategy and Study Selection. The systematic search and review processes were conducted in accordance with the Preferred Reporting Items for Systematic Reviews and Meta-Analyses (PRISMA) Statement criteria as proposed by Liberati et al. [22]. We searched SCOPUS, PubMed, MEDLINE (http://www.ncbi.nlm.nih.gov/pubmed/), and EMBASE (http://www.embase.com/home) databases using the following search terms: "Ghana" successively combined with "heavy metals," "pollutant," "toxic element," "metalloid," "arsenic," "cadmium," "mercury," "lead," "cobalt," “zinc," "manganese," “iron," "nickel," and "chromium.” The search was limited to papers published till January 2013 and yielded 1004 bibliographic records. The bibliographic records were complemented with attempts of search for other research by key authors and search of citations and reference lists of key reports and related articles. After importing bibliographic records duplicates were deleted and reports were scrutinized using Zotero 2.03. All studies presenting quantitative data on levels of arsenic, cadmium, lead, mercury, chromium, cobalt, nickel, manganese, iron, tin, and zinc in environmental media (soil, water, sediment, and air) and or biologic specimen (hair, urine, blood, nails, and food) were included, regardless of experimental design, or methods of collection of samples, or chemical analysis.

2.2. Data Extraction. Using a standard, purpose-designed form, we extracted the following data from each paper: (a) study design, date and place, sampling method and size, inclusion and exclusion criteria, and request for informed consent; (b) protocol for collection, storage, processing, and analysis of biologic specimens; and (c) results, including metal levels and related factors.

\section{Results}

3.1. Description of the Studies. Of 1004 bibliographic records of relevance to the gold mining context in Ghana identified, 594 did not meet inclusion criteria at first screening, 83 fulltext articles were sought for full-text screening, and 65 were obtained and screened. Fifty-four studies were included in evidence synthesis. Searching, screening, and study inclusion are summarized in the flow diagram, Figure 1.

The main characteristics of each study are described in Tables 3, 4(a)-4(c), and 5(a)-5(e). Whereas older studies (from mid 1970s through early 1990s) on heavy metals in environmental media and biologic specimens in Ghana were mainly undertaken along the Ashanti gold belt in south western Ghana (to a large extent in Obuasi and to some extent in Tarkwa), studies targeting environmental media in 


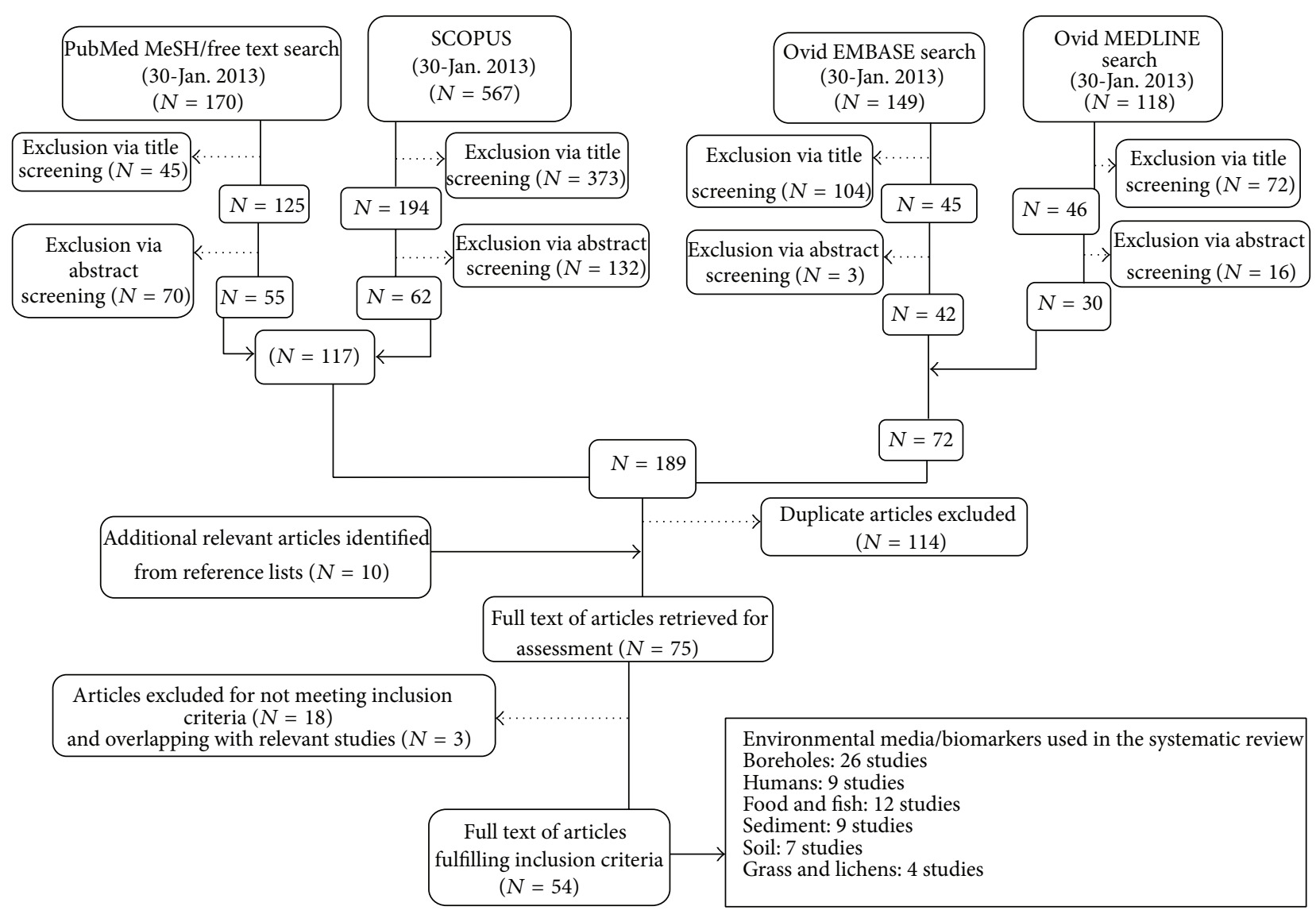

FIGURE 1: Schematic diagram of search strategy.

the northern parts of Ghana began to be published only in the early 2000s and accounted for an ample fraction (20\%) of published works from 2000 and later. Of the reviewed articles, the earliest study on heavy metals in environmental media and biologic specimens in Ghana was undertaken by Simeonov et al. [23]. Thereafter, there was an almost twentyyear lull in research on heavy metals before the work of Amonoo-Neizer and Amekor [14].

3.2. Research Design and Objectives. All the papers reviewed were cross-sectional studies with three distinct types of objective, often combined in the same study, that is, assessment of levels of heavy metals in the media, spatial variability of the metals, and compliance with environmental and regulatory standards. None of the studies monitored heavy metal concentrations in environmental media or biologic specimens across time (longitudinally). Broadly, studies adopted either an environmental monitoring or a bio-monitoring perspective. A disproportionately large number of papers (about $80 \%$ ) focused exclusively on environmental media. Out of the 54 articles reviewed, twelve papers devoted attention to heavy metals in either cooked (fish) or uncooked food (vegetables, fruits) or other plants (lichens).

Papers focusing on biomonitoring and human health were few and far between. In total, 10 articles focused on heavy metals in humans. As shown in Tables 1(a) and 1(b), six papers analysed heavy metals in human hair. Eight manuscripts measured heavy metals in human urine and only two articles focused on heavy metals in human blood. Also, two measured heavy metals in human nails. Of the studies reporting on human subjects, only one reported on 1 biomarker of exposure (hair), whereas another study reported on three biomarkers (hair, blood, and urine). The rest reported on at most two biomarkers (see Tables 1(a) and 1(b)). Regarding ethical considerations, 6 papers on human subjects specifically mentioned informed consent as a prerequisite for study participation and 2 papers, mostly recent, stated the approval of an ethics committee.

3.3. Analytical Methods: Collection, Processing, and Analysis of Biologic Specimens. Period of collection of environmental samples and biologic specimens, which was not always specified, varied extensively as shown in Table 3. For instance, more than $20 \%$ of articles reviewed did not report period of data collection (11 papers). Similarly, pretreatment of environmental samples, which was not always specified, varied widely. In general, the environmental and biologic samples (water, urine, blood, etc.) were frozen and stored before laboratory analyses. A variety of spectrometry was used to determine levels of heavy metals. These include UV-visible spectrophotometry (2 papers), cold vapour atomic absorption spectrophotometry (5 papers), instrumental neutron 


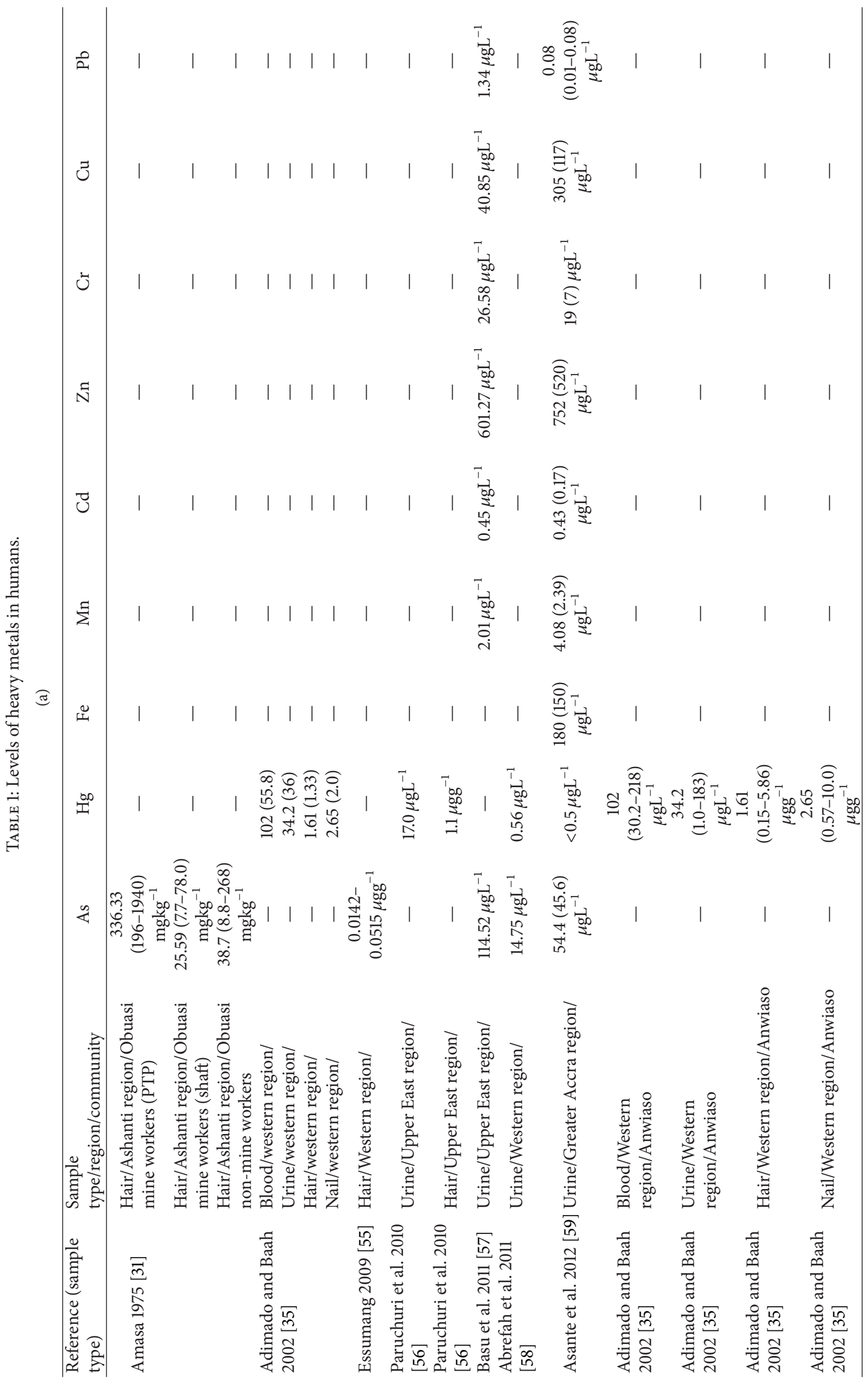




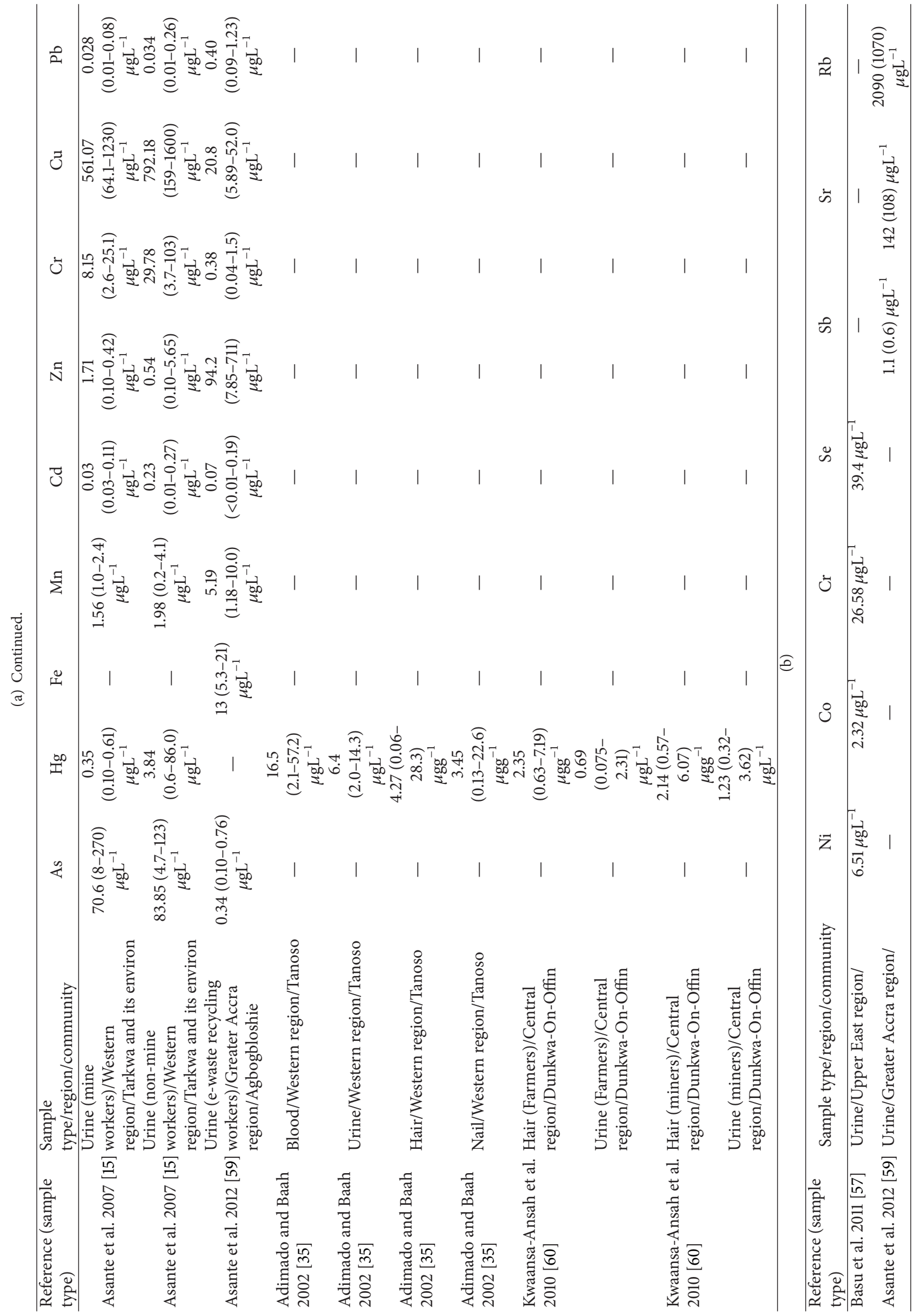




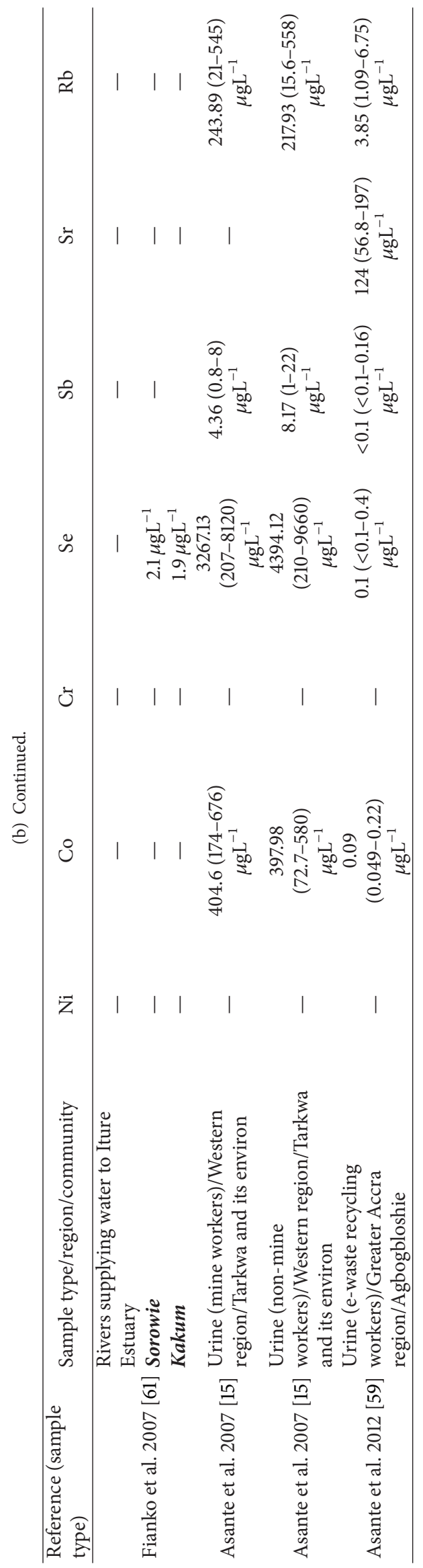


activation analysis (10 papers), inductively coupled plasma mass spectrometry (ICP-MS) (4 papers), and inductively coupled plasma-optical emission spectroscopy (ICP-OES) (1 paper). Other techniques included flame atomic absorption spectrophotometry (12 papers), high performance liquid chromatography (HPLC) (1 paper), inductively coupled plasma atomic emission spectrometer (ICP-AES) (1 paper), and atomic absorption spectrophotometry (6 papers). Five studies did not report the analytical method used in the determination of heavy metals in environmental media or biologic samples.

Information on laboratory quality controls differed between the earliest and the more recent papers. Before the year 2000, none of the studies specified having internal quality controls or external controls. In contrast, all studies published after 2005 (7 papers) reported the use of standardized quality control procedures that generally comprised evaluation of accuracy and precision by analysis of certified reference material; however, no studies included additional inter-laboratory comparisons. Only about one-third of the studies specified the limit of detection (LOD), merely stating the value or including the procedure used to treat values below it.

3.4. Statistical Analyses and Reporting of Results. Most of the studies (>90\%) provided measures of central tendency, that is, arithmetic means, usually accompanied by standard deviations (SDs). Geometric mean was not reported in any of the papers. Other widely used indicators of dispersion and central tendencies were range (more than 40 studies) and median (15 studies). Without exception, authors neither include confidence intervals nor mention the evaluation of outliers or the use of robust measures of central trend. Studies assessing associations with risk factors generally provided either Pearson's product moment or Spearman's correlation coefficients drawn from univariate analyses or differences in means derived from stratified analyses; few papers ( 2 papers) carried out multivariate analyses.

3.5. Levels of Heavy Metals in Underground Water and Water from Boreholes. Studies reported a high degree of spatial variability for the concentrations of 8 metals (As, $\mathrm{Hg}, \mathrm{Cd}$, $\mathrm{Cr}, \mathrm{Pb}, \mathrm{Co}, \mathrm{Sr}$, and $\mathrm{Mn}$ ) in boreholes as shown in Table 2. The lowest concentration of As $\left(<1 \mu \mathrm{gL}^{-1}\right)$ was reported by Akabzaa et al. [24] for the Anglogold Ashanti area in Obuasi. The highest concentration of As $\left(12200 \mu \mathrm{gL}^{-1}\right)$ was reported by Boadu et al. [25] for the Konongo Old mining shaft. The lowest concentration of $\mathrm{Hg}\left(<0.05 \mu \mathrm{gL}^{-1}\right)$ was reported by Asante et al. [15] for the Tarkwa gold mining area, whereas the highest $\mathrm{Hg}$ concentration of $6251 \mu \mathrm{gL}^{-1}$ was reported by Essumang et al. [16] for the Wassa West District. The lowest concentration of $\mathrm{Cd}\left(<0.06 \mu \mathrm{gL}^{-1}\right)$ was reported by Asante et al. [15] for the Tarkwa gold mining area and the highest $\mathrm{Cd}$ concentration of $7.6 \mu \mathrm{gL}^{-1}$ was reported by Tay and Momade [26] for the northern part of the Ashanti gold belt. The lowest concentration of $\mathrm{Cr}\left(0.03 \mu \mathrm{gL}^{-1}\right)$ was reported by Asante et al. [15] for the Tarkwa gold mining area, whereas the highest $\mathrm{Cr}$ concentration of $45 \mu \mathrm{gL}^{-1}$ was reported by Essumang et al. [16] for the Dumasi community in the Wassa West District. Three studies [15, 24, 27], severally reported the lowest $\mathrm{Pb}$ concentration of $0.01 \mu \mathrm{gL}^{-1}$. However, Akabzaa et al. [24] reported the highest $\mathrm{Pb}$ concentration $\left(96 \mu \mathrm{gL}^{-1}\right)$ within the vicinity of the Obuasi goldmine. The lowest concentration of Co $\left(0.02 \mu \mathrm{gL}^{-1}\right)$ was reported by Asante et al. [15] for the Tarkwa gold mining area, whereas the highest Co concentration of $50 \mu \mathrm{gL}^{-1}$ was reported by Essumang et al. [16] for the Dumasi community in the Wassa West District.

3.6. Levels of Heavy Metals in Riverine Sediments and Soil. There was a high degree of variability in metal concentrations in riverine sediments and soil reported by the studies reviewed (Table 4). The lowest concentration of As in sediment was reported by Akabzaa et al. [24] for the Anglogold Ashanti area in Obuasi and the highest As concentration $\left(10,200 \mathrm{mgkg}^{-1}\right)$ was reported by Serfor-Armah et al. [28] for Prestea in the Western region of Ghana. The lowest concentration of $\mathrm{Hg}\left(0.01 \mathrm{mgkg}^{-1}\right)$ was reported by Boamponsem et al. [29] for Teberebie spring 3 in the Tarkwa gold mining area. Also, Boamponsem et al. [29] reported the highest concentration of $\mathrm{Hg}\left(200 \mathrm{mgkg}^{-1}\right)$ for bottom sediments of the Offin River basin. The highest concentration of $\mathrm{Pb}\left(115 \mathrm{mgkg}^{-1}\right)$ was reported by Akabzaa et al. [24] for communities immediately downstream of the Anglogold Ashanti mine in Obuasi.

Generally, heavy metal concentrations in soil reported by the studies reviewed were higher than metal concentrations in riverine sediments. Studies reviewed did not report on Mn, $\mathrm{Ni}$, or $\mathrm{Pb}$ concentrations in soil. The lowest As concentration $\left(0.7 \mathrm{mgkg}^{-1}\right)$ in soil was reported by Hayford et al. [30], whereas the highest As concentration $\left(2875 \mathrm{mgkg}^{-1}\right)$ in soil was reported by Amasa [31]. The lowest concentration of $\mathrm{Hg}\left(\mathrm{mgkg}^{-1}\right)$ in soil was reported by Oppong et al. [32] for the Pra River basin at Daboase, Western Ghana. The highest concentration of $\mathrm{Hg}\left(2146 \mathrm{mgkg}^{-1}\right)$ was reported by Donkor et al. [33] for the Offin River basin.

3.7. Levels of Heavy Metals in Fruits, Vegetables, and Edible Plants. Generally, studies reviewed focused mainly on the chemical content of certain elements in the biologic specimen. None focused on the influence of heavy metals on the morphological or cellular structure or metabolicbiochemical processes in the biologic specimen. Some of the studies categorised the food items analysed into cooked and uncooked (e.g., [14]), whereas others did not distinguish between the cooked and uncooked forms [24]. Only one study [34] reported on heavy metals using lichens as biologic specimen in the Obuasi gold mining area. Similarly, one study [14] used star grass as biologic specimen. However, two studies $[19,31]$ used ferns and two other studies [14, 19] used elephant grass as biologic specimen. Several fruits and vegetables were used in the studies reviewed as biologic specimen. The vegetables include pepper, beans, cocoyam, cassava, and plantain. Fruits include oil palm, cocoa, sugar cane, pear, orange, and banana. 


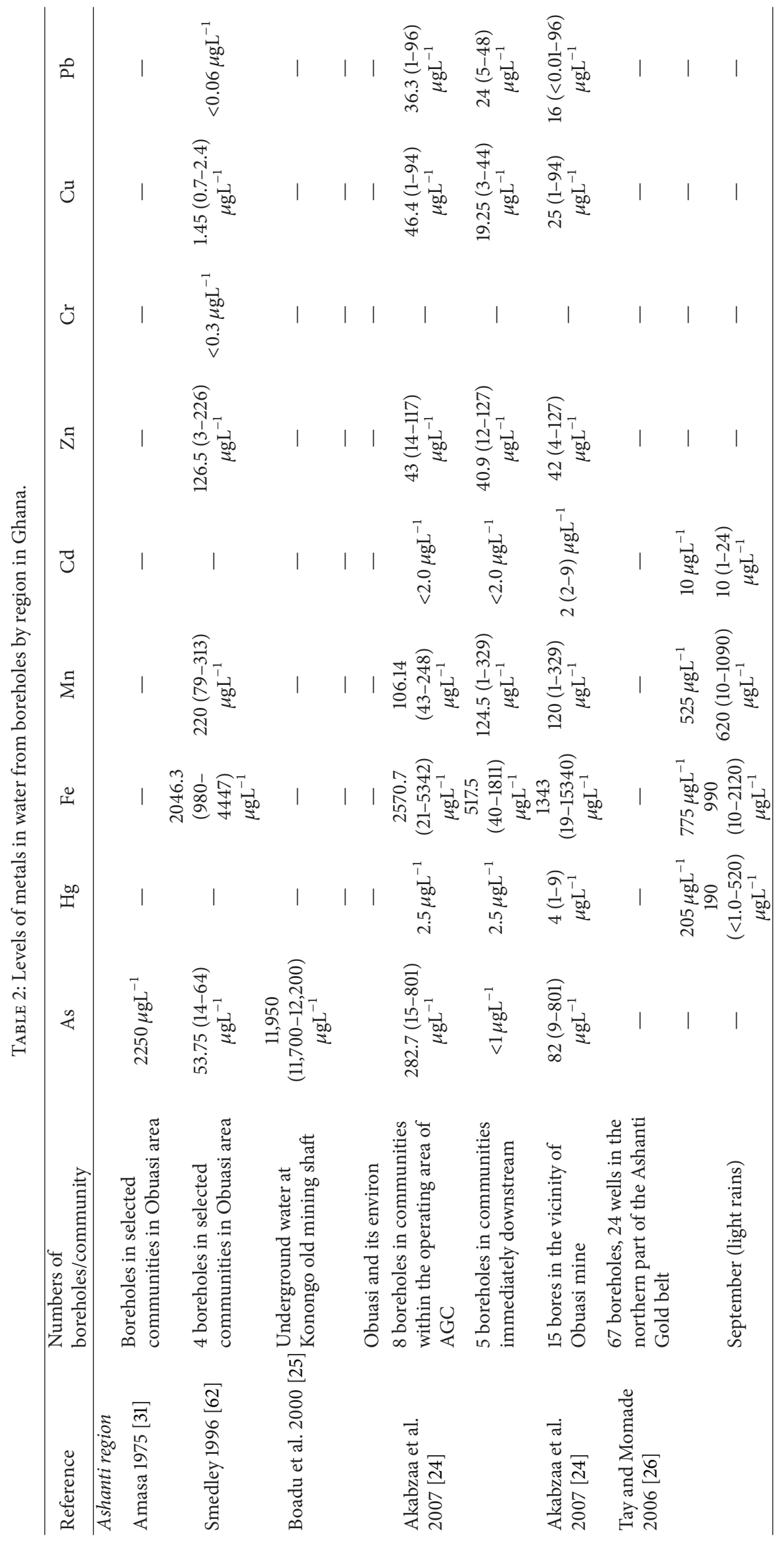




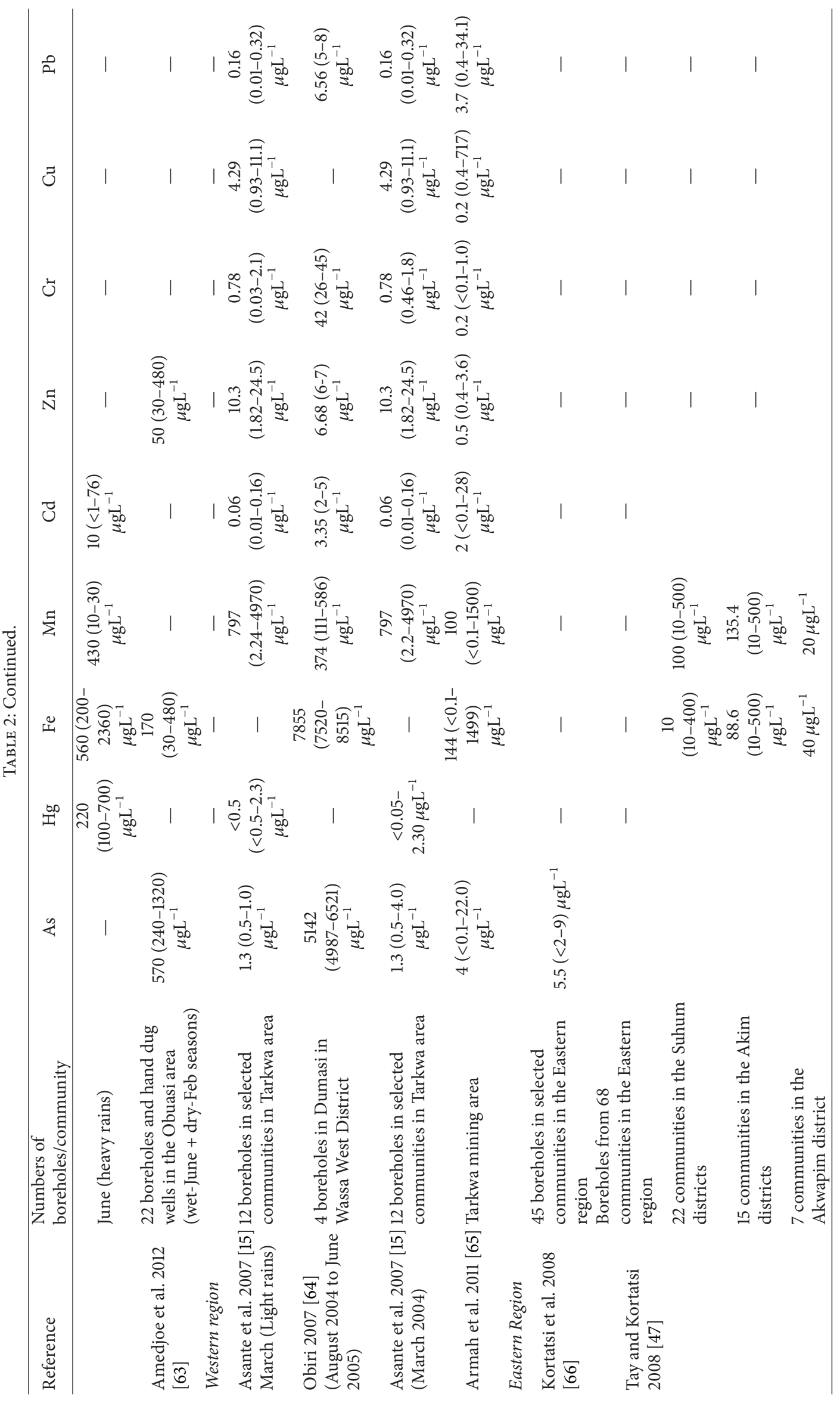




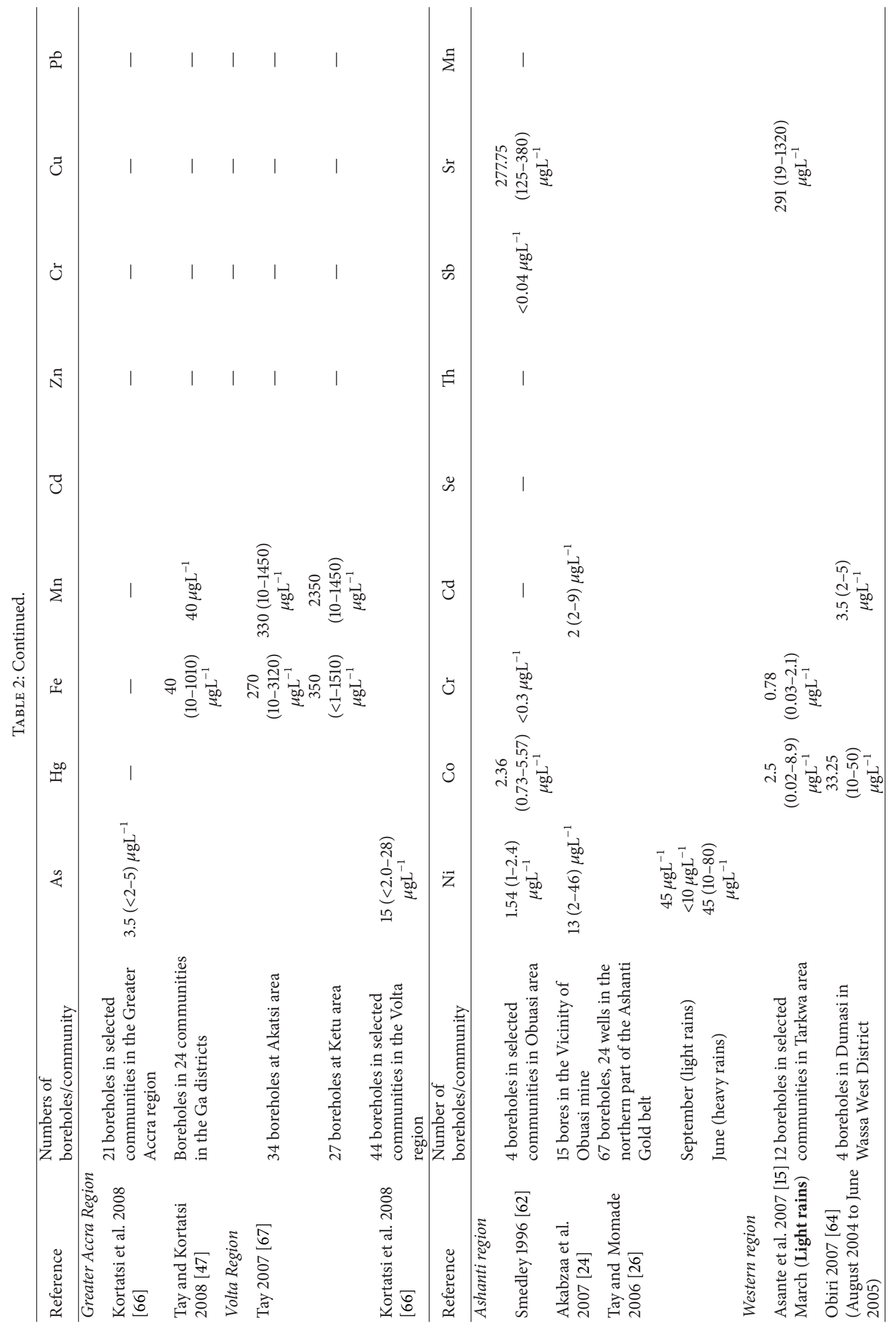




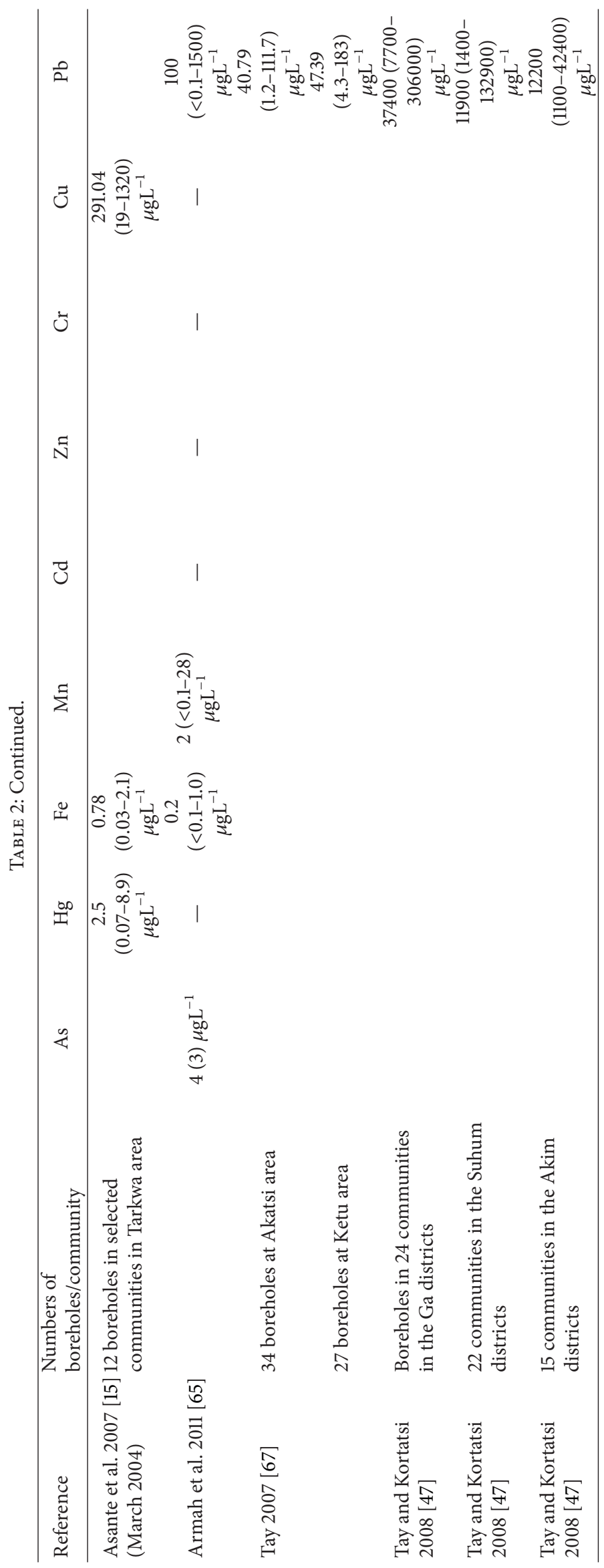




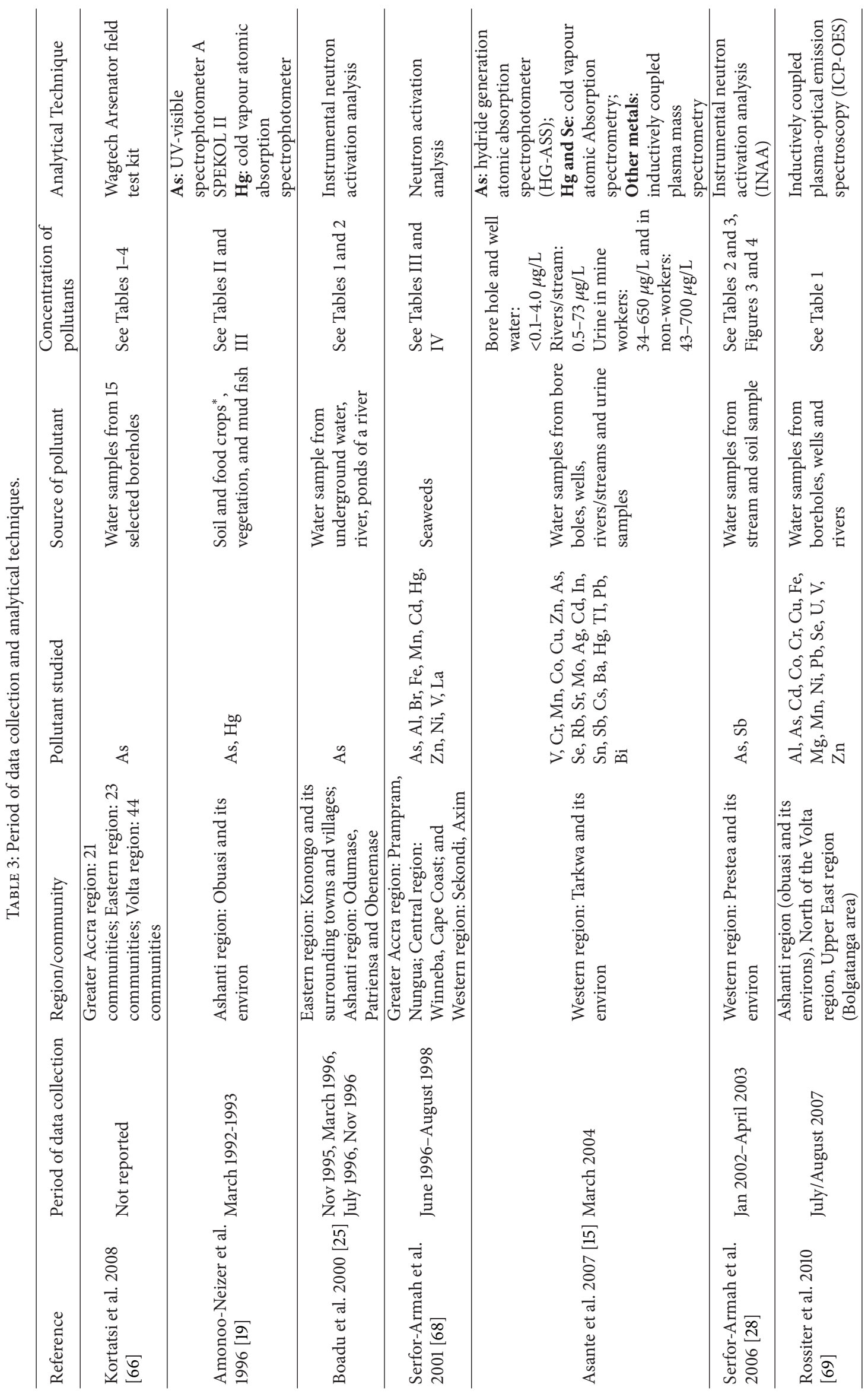




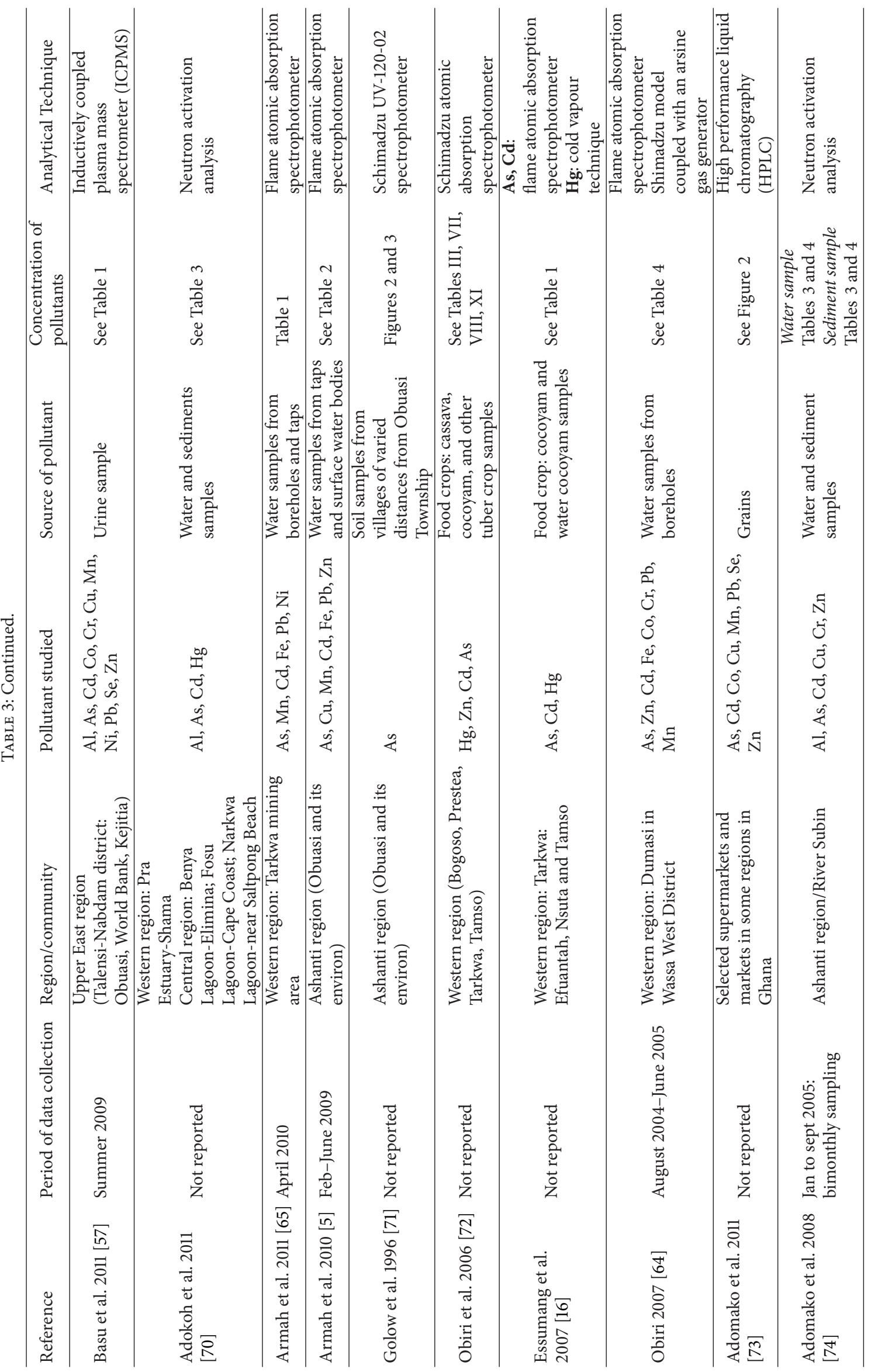




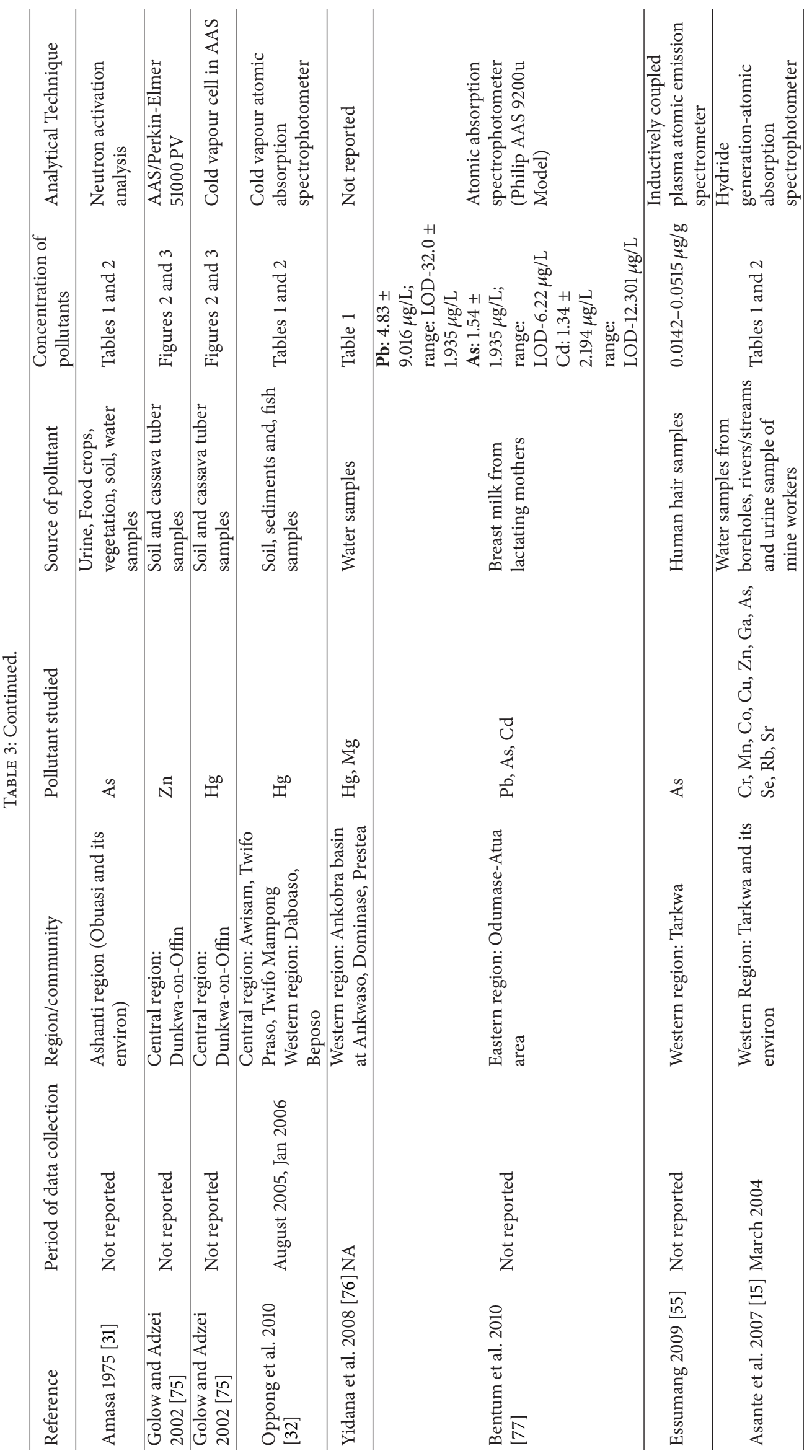




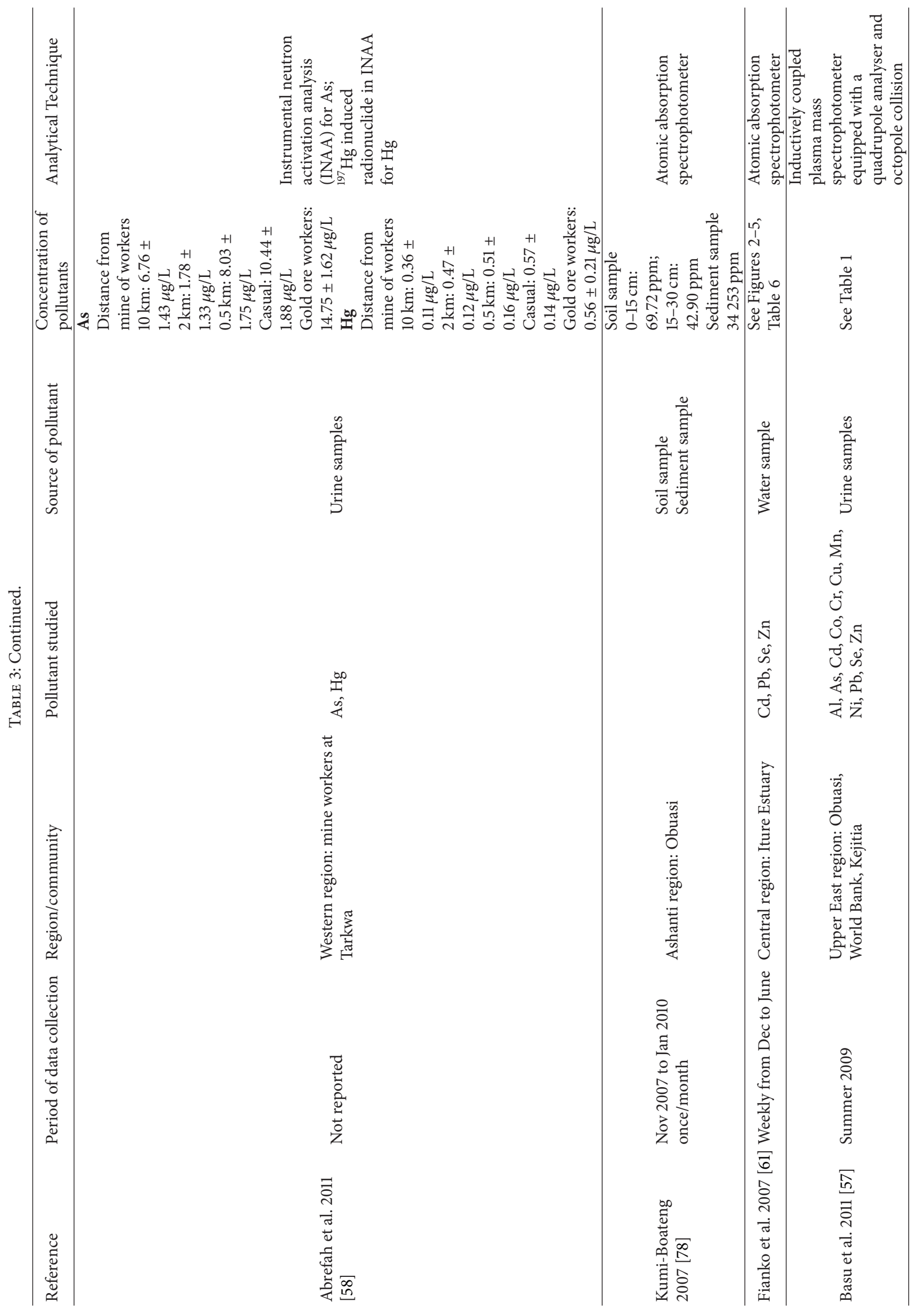




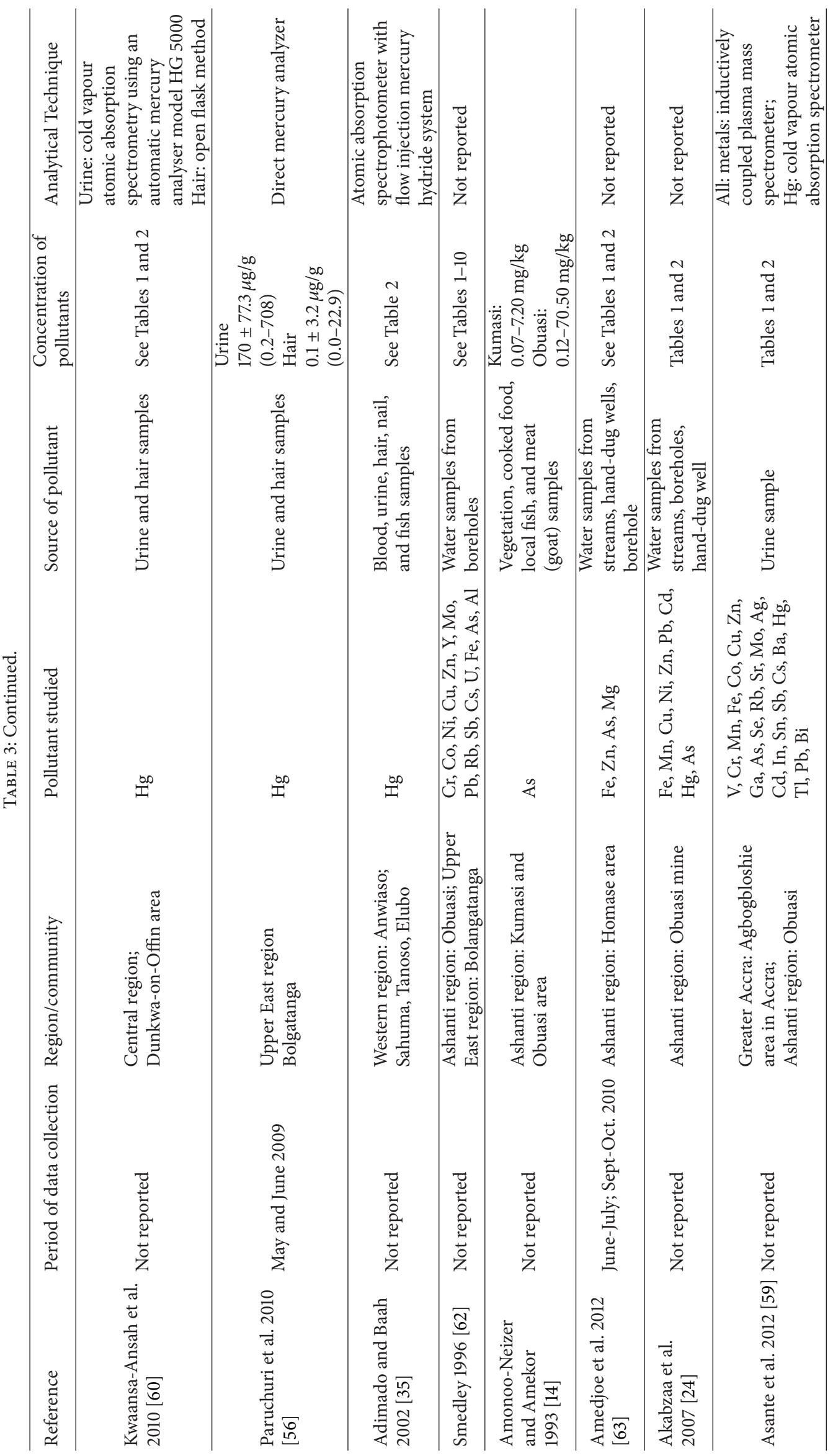




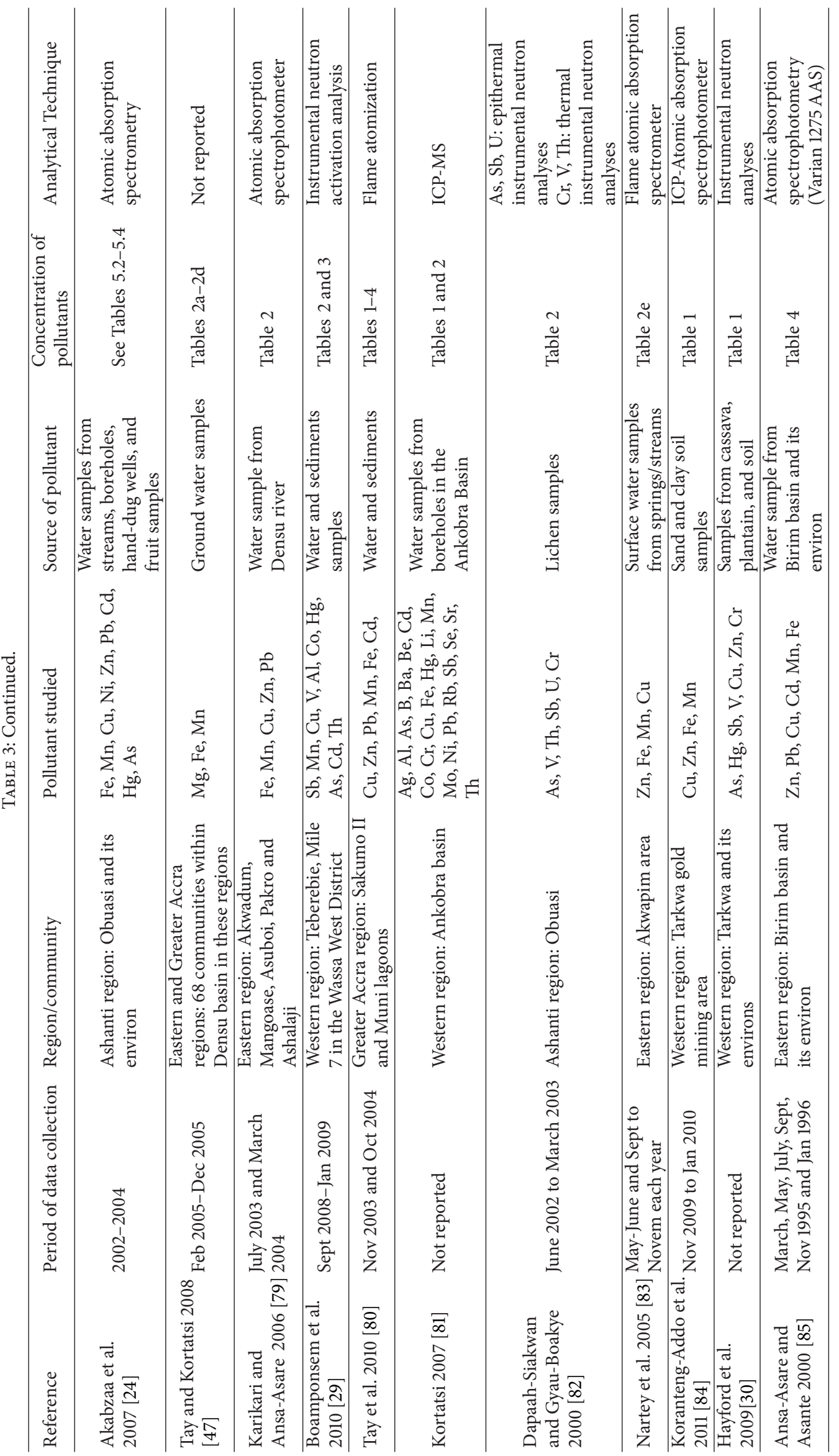




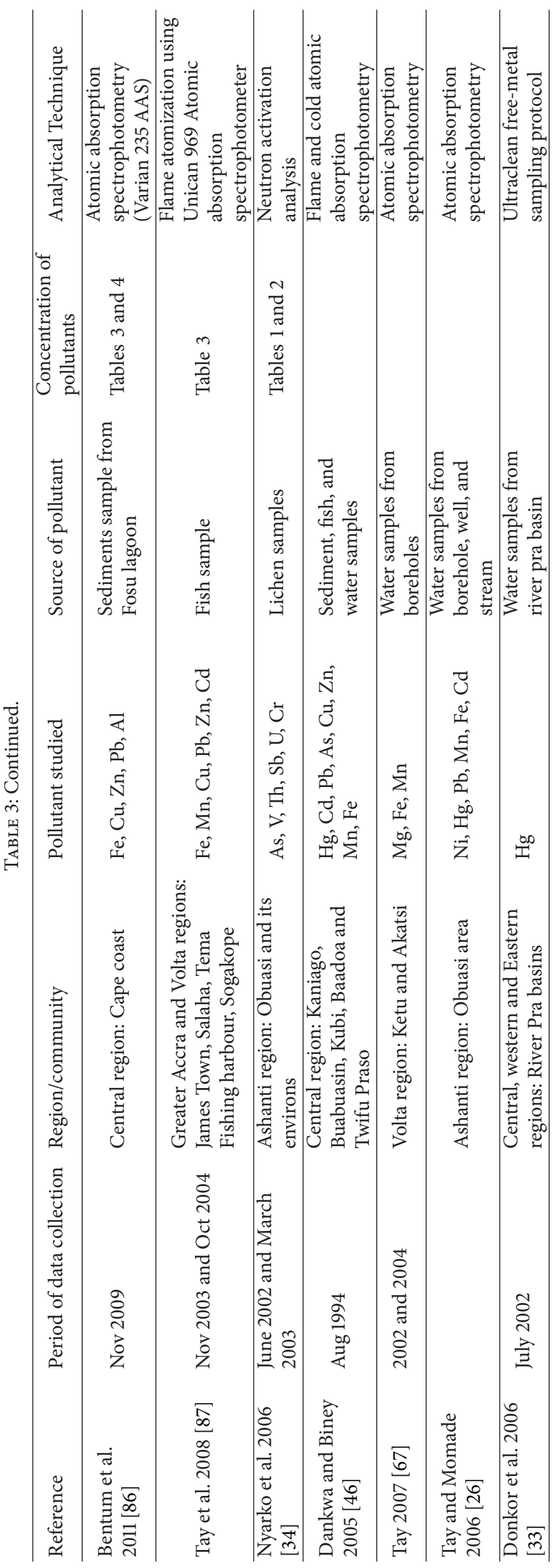




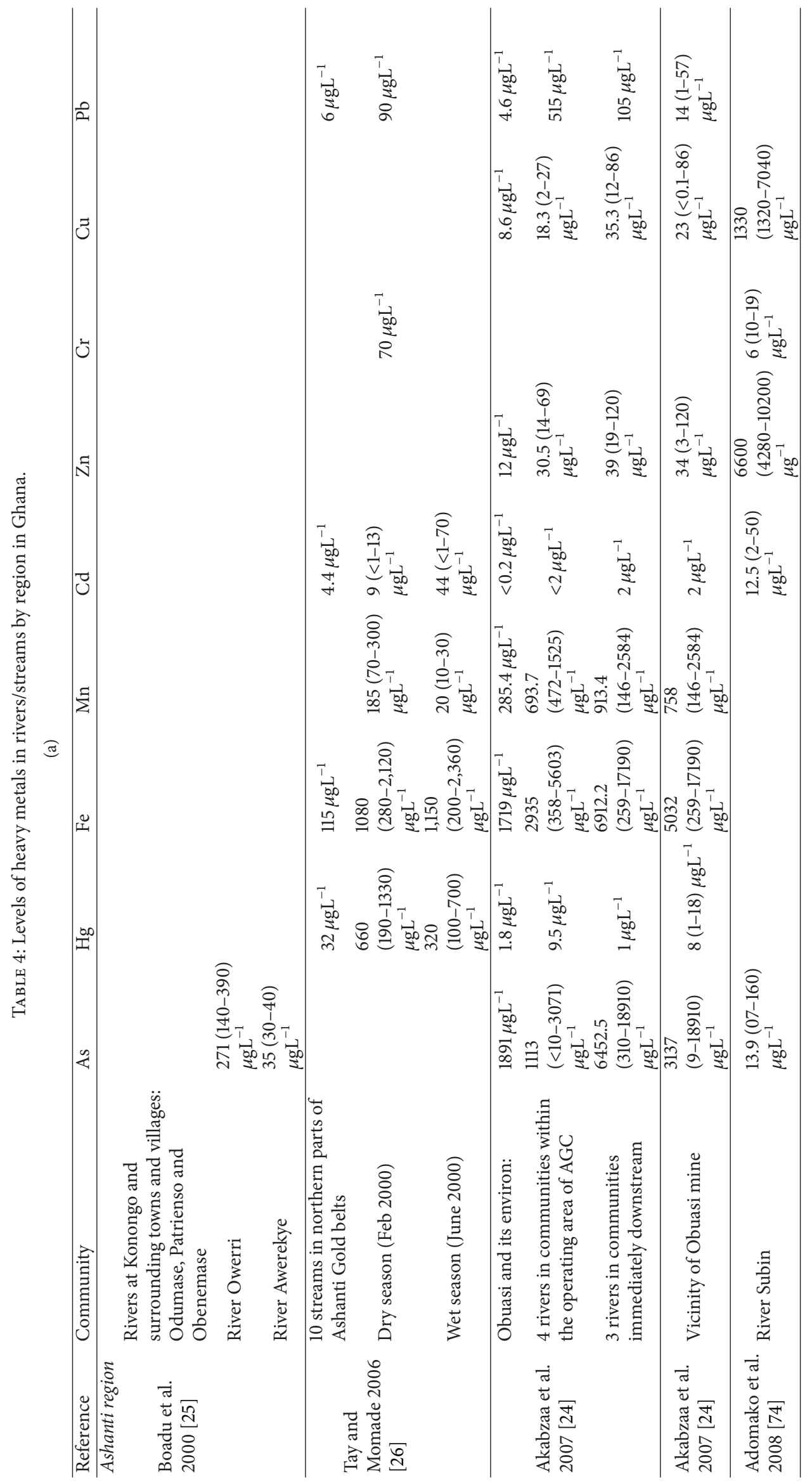




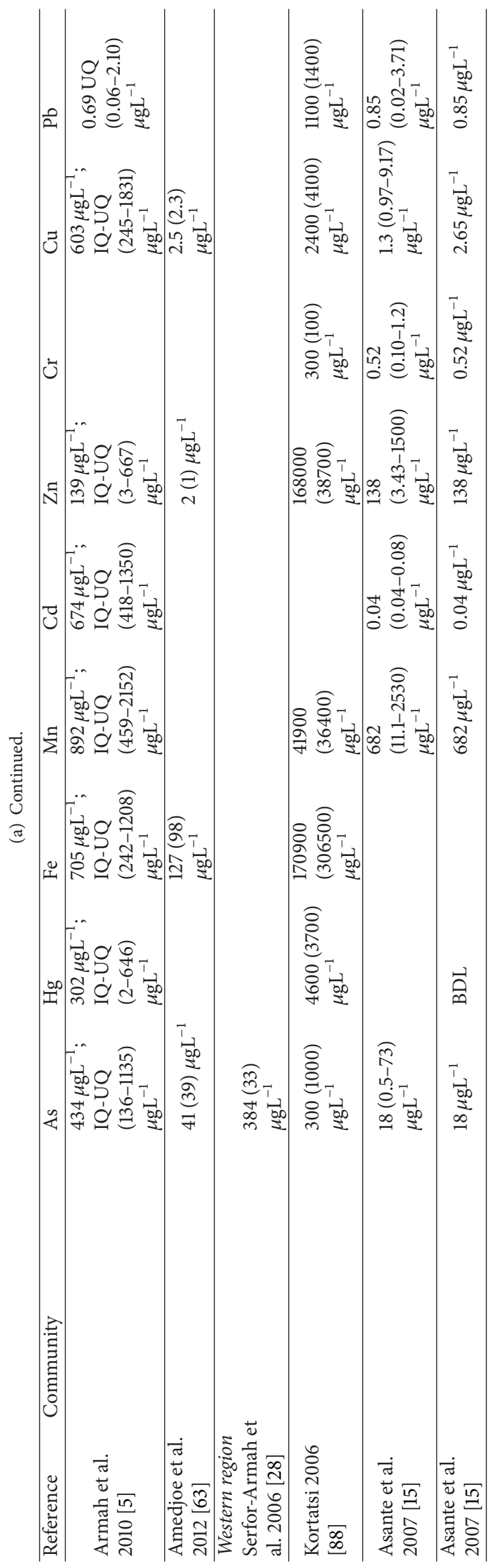




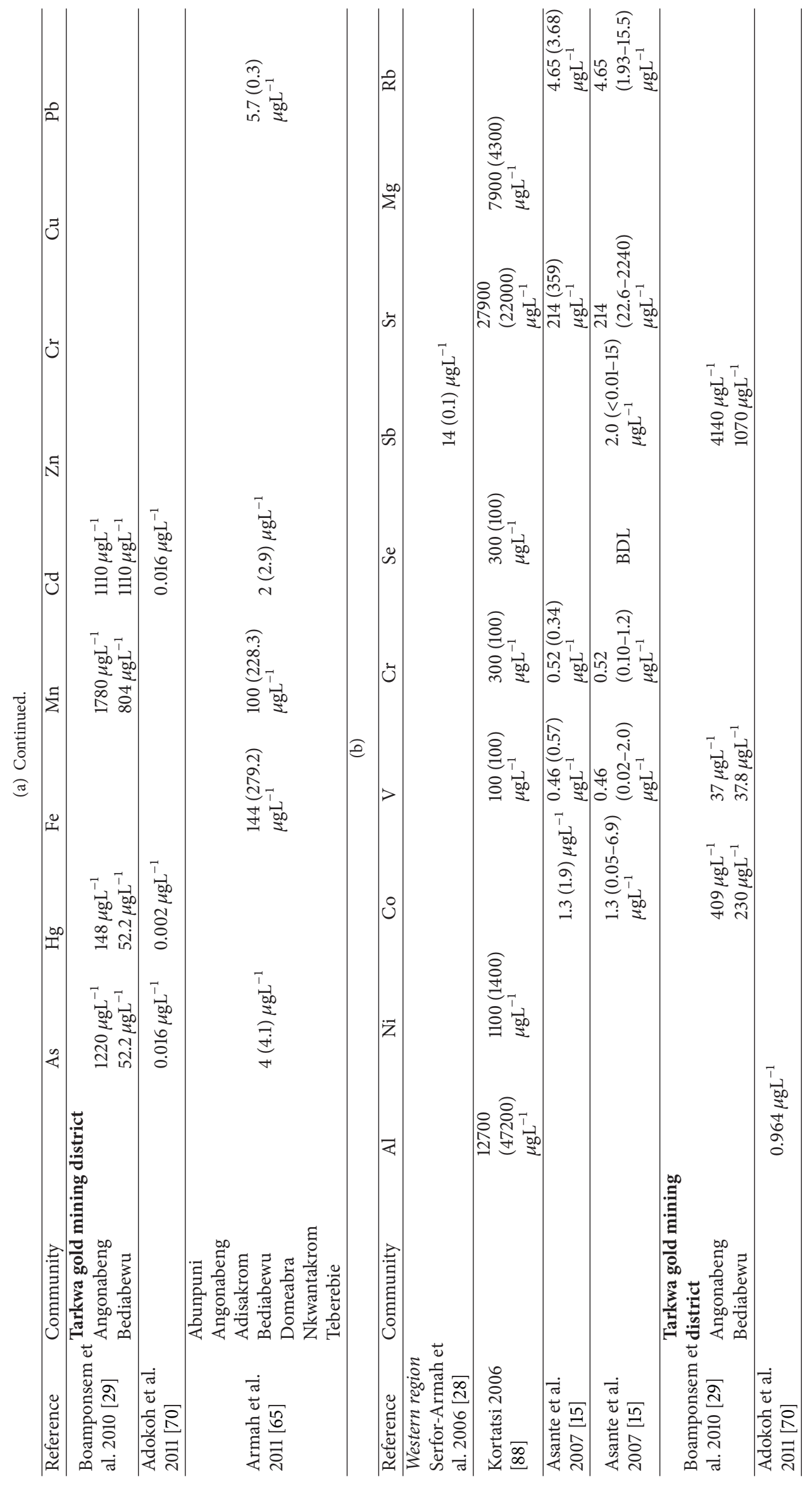




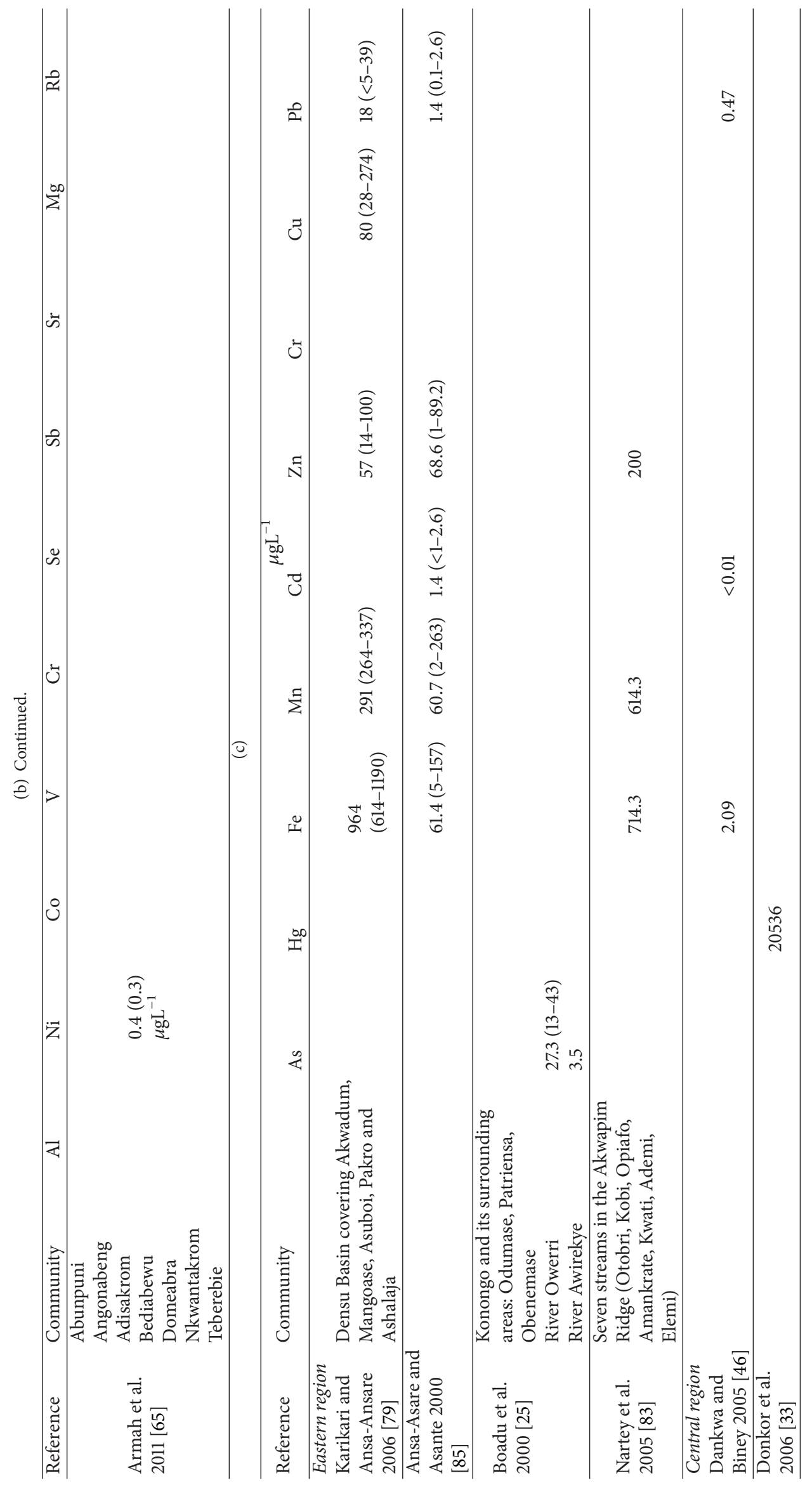




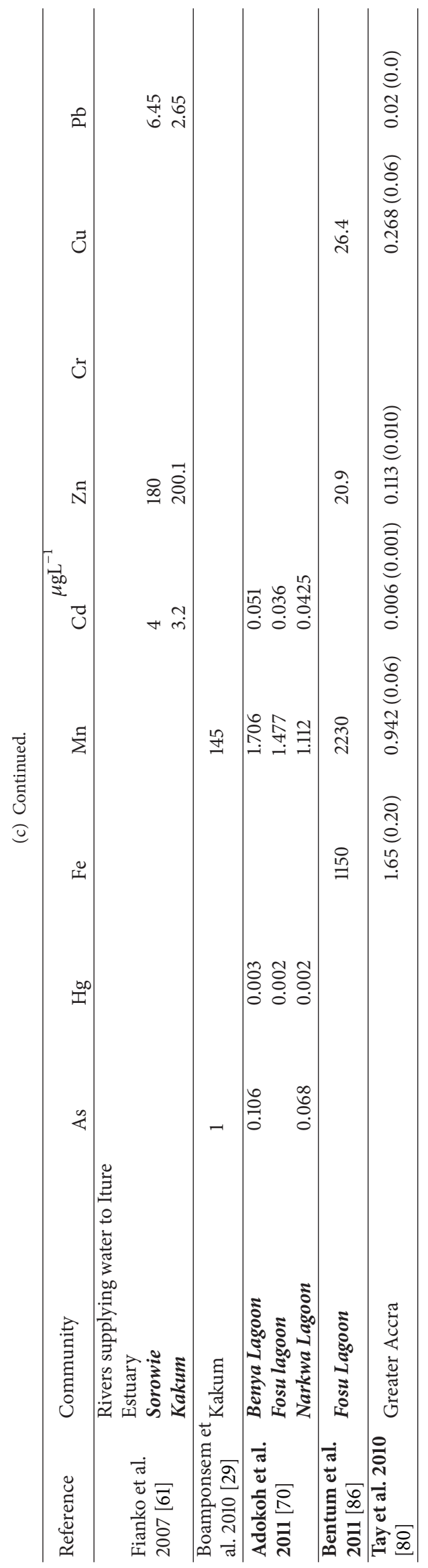


Amasa [31] reported very high concentration of As in ferns (up to $4700 \mathrm{mgkg}^{-1}$ ) and oil palm $\left(2900 \mathrm{mgkg}^{-1}\right.$ ). The lowest As concentrations were reported for plantain $\left(2.29 \mathrm{mgkg}^{-1}\right)$ and cassava $\left(2.65 \mathrm{mgkg}^{-1}\right)$ in Obuasi and its environs (Tables 5(a)-5(e)). Generally, the magnitude of As concentrations in soil and biologic specimen in decreasing order as reported by the studies reviewed was as follows: palm tree $>$ fern $>$ soil $>$ sugar cane $>$ banana $>$ orange $>$ cocoyam $>$ cassava $>$ plantain. Essumang et al. [16] reported As concentrations as high as 383 in water cocoyam grown in soils of the Tarkwa gold mining area. The magnitude of $\mathrm{Hg}$ concentrations in soil and biologic specimen in decreasing order as reported by the studies reviewed was as follows: fern $>$ soil $>$ elephant grass $>$ plantain $>$ cassava.

3.8. Levels of Heavy Metals in Urine and Blood. Studies reviewed broadly reported heavy metals concentrations in urine for gold mine workers, non-gold mine workers, and workers exposed to fumes from e-waste recycling. Urine was the most common biological marker of heavy metal exposure used by the studies reviewed. Generally, reports on the levels of heavy metals in gold mining workers and their non-gold mining counterparts did not reveal any discernible pattern. For instance, from Asante et al. [15] it can be deduced that the non-mine worker/mine worker ratios for $\mathrm{As}, \mathrm{Hg}$, $\mathrm{Mn}, \mathrm{Cd}, \mathrm{Zn}, \mathrm{Cr}, \mathrm{Cu}$, and $\mathrm{Pb}$ were $1.2,10.9,1.3,7.7,0.3,3.7$, 1.4 , and 1.2, respectively. This suggests that except $\mathrm{Zn}$ nonmine workers generally had lower concentrations of heavy metals in their urine compared to their counterparts who were mine workers. This result is counter-intuitive. Heavy metals in urine samples of small scale artisanal gold miners in the Upper East region did not differ significantly from heavy metals in urine samples of e-waste recyclers in Accra. Only one study [35] reported on heavy metals in blood samples mostly in some residents in the Western region of Ghana. Mercury levels in such residents varied spatially. For instance, Adimado and Baah [35] reported $\mathrm{Hg}$ concentrations of $218 \mu \mathrm{gL}^{-1}$ and $57 \mu \mathrm{gL}^{-1}$ for residents in Bibiani Anhwiaso Bekwai and Tanoso, in south western Ghana.

3.9. Levels of Heavy Metals in Hair and Nails. Hair was the second most common biological marker of heavy metal exposure used by the studies reviewed unlike nails, which were sparingly used. Generally, concentrations of heavy metals reported by the studies reviewed for nails were higher than for hair. One study [35] reported higher concentrations of heavy metals in nails than in hair.

\section{Discussion}

In this review, we provide a systematic categorisation of the results of studies published from 1975 to January 2013 on $\mathrm{As}, \mathrm{Hg}, \mathrm{Cd}, \mathrm{Zn}, \mathrm{Sb}, \mathrm{Cr}, \mathrm{Fe}, \mathrm{Co}, \mathrm{Cu}, \mathrm{Ni}, \mathrm{Zn}, \mathrm{Mn}$, and $\mathrm{Pb}$ levels in water, soil, sediment, fruits, and vegetables as well as human hair, urine, blood, and nails in Ghana. We found that the use of vegetables, fruits, fish, hair, nails, and blood as biomarkers of exposure to heavy metals is not appropriately developed because of the heterogeneity among the studies. This heterogeneity applies not only to the populations selected and the analytical techniques (as it impinges on accuracy and precision) but also to the processing of specimens and presentation of results. The procedure for collection, pretreatment, storage, and preparation of the heavy metals prior to analysis varied extensively among studies, although available data suggest that such processes may influence the magnitude and comparability of the trace metal concentrations $[36,37]$.

It would appear that large variability in measured concentrations, apart from collection methods as mentioned above, was likely the result of differences in spatial characteristics of the sampling locations. Similarly, for the published studies that focused on human subjects, the variability in measured concentrations may emanate from varying excretion profiles amongst widely varying individuals with ranges of body burdens, genetic polymorphisms affecting detoxification efficiency, and physiological states [38]. These variations were very much greater than would be expected due to limitations of analytical methods. Although analytical methods have improved over the years, analysis of these metals was routine at the time of the studies.

Apart from geogenic sources, the contamination chain of heavy metals emanating from anthropogenic sources almost always follows a cyclic order: industry, atmosphere, soil, water, foods, and humans [39]. Regarding exposure to contaminants in environmental media, surface and groundwater were the most studied. Published results clearly indicate widespread contamination of ground and surface water especially in gold mining environments. Groundwater quality in natural systems is a result of many environmental factors. Climate, geology, biochemistry, composition of atmospheric precipitation, and the nature of the hydrology are among the more important factors [39].

Arsenic concentrations in aquifers in different geologic settings vary considerably over short distances. In the mining communities the geologic settings are Tarkwaian or Birimian systems [40]. Arsenic in groundwater occurs in two species (chemical forms), As (III) and As (V), which denote the As oxidation state. Arsenic $(\mathrm{V})$ consists of arsenic acid $\left(\mathrm{H}_{3} \mathrm{AsO}_{4}\right)$ and its conjugate bases $\left(\mathrm{H}_{2} \mathrm{AsO}_{4}{ }^{-}, \mathrm{HAsO}_{4}{ }^{2-}\right.$, and $\left.\mathrm{AsO}_{4}{ }^{3-}\right)$. In the $\mathrm{pH}$ range of most natural waters, the predominant $\mathrm{As}$ (V) species are the anions $\mathrm{H}_{2} \mathrm{AsO}_{4}{ }^{-}$and $\mathrm{HAsO}_{4}{ }^{2-}$ [39]. In the same $\mathrm{pH}$ range, As (III) consists of mostly uncharged arsenious acid $\left(\mathrm{H}_{3} \mathrm{AsO}_{3}\right)$ with a minor amount $(<10 \%)$ of the anion $\mathrm{H}_{2} \mathrm{AsO}_{3}{ }^{-}$which sorbs As (III) $[39,41]$. The predominant As species in groundwater in the mining communities (i.e., Bogoso, Tarkwa, Teberebie, Damang) is As (III), which is obtained from the oxidation of FeAsS (arsenopyrite) ore abundant in these communities [40]. Most of ingested arsenic is rapidly excreted via the kidney within a few days. However, high levels of arsenic are retained for longer periods of time in the bone, skin, hair, and nails of exposed humans [36].

Iron concentration in groundwater varied extensively with location. The inconsistent value of Fe obtained in this study is not unexpected owing to the high occurrence of the metal in nature. Fe constitutes a high weight percentage in sulphide ores and is therefore likely to be very high, at areas of active metallurgic activity such as Tarkwa, Damang, and 


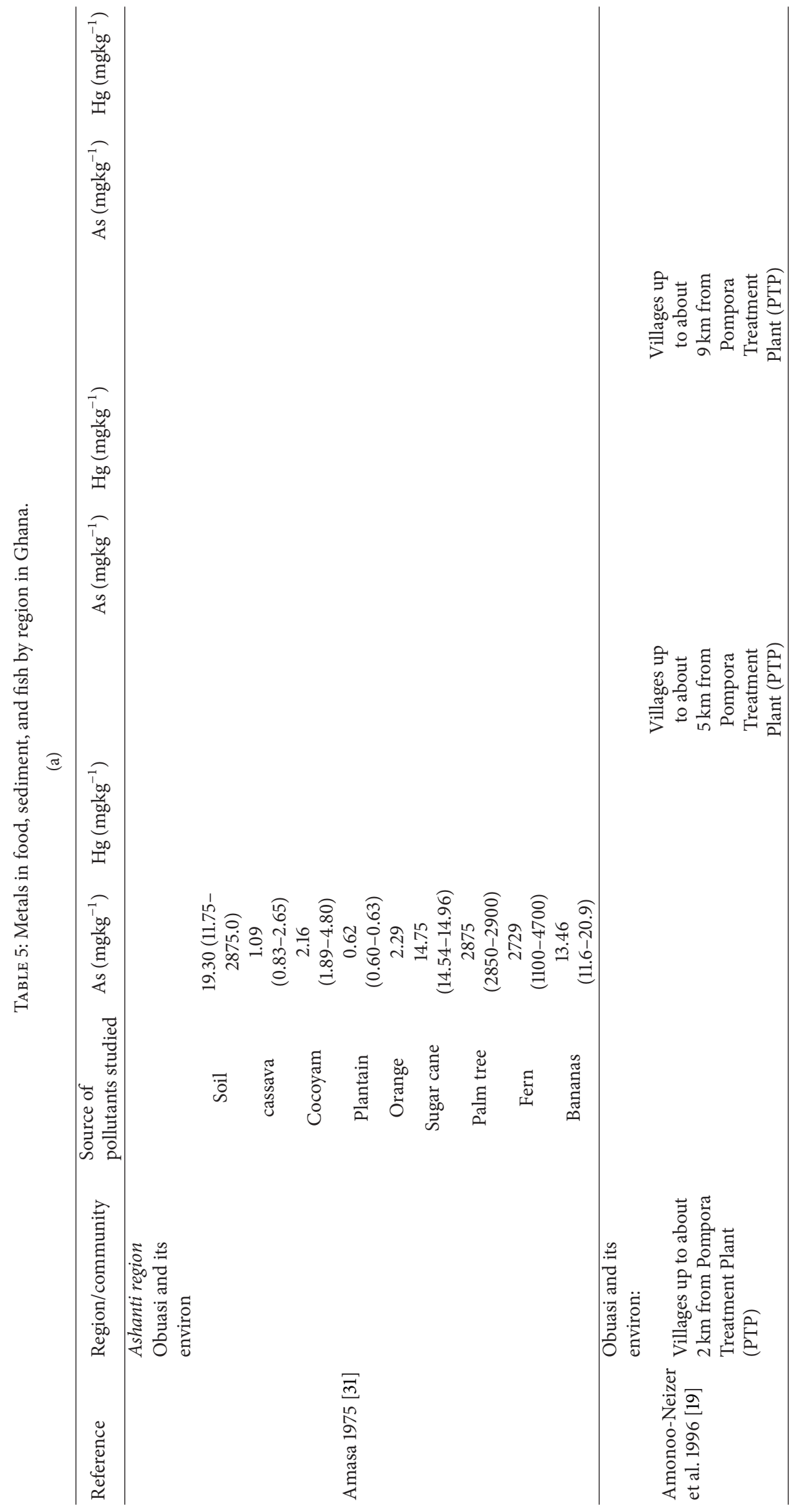




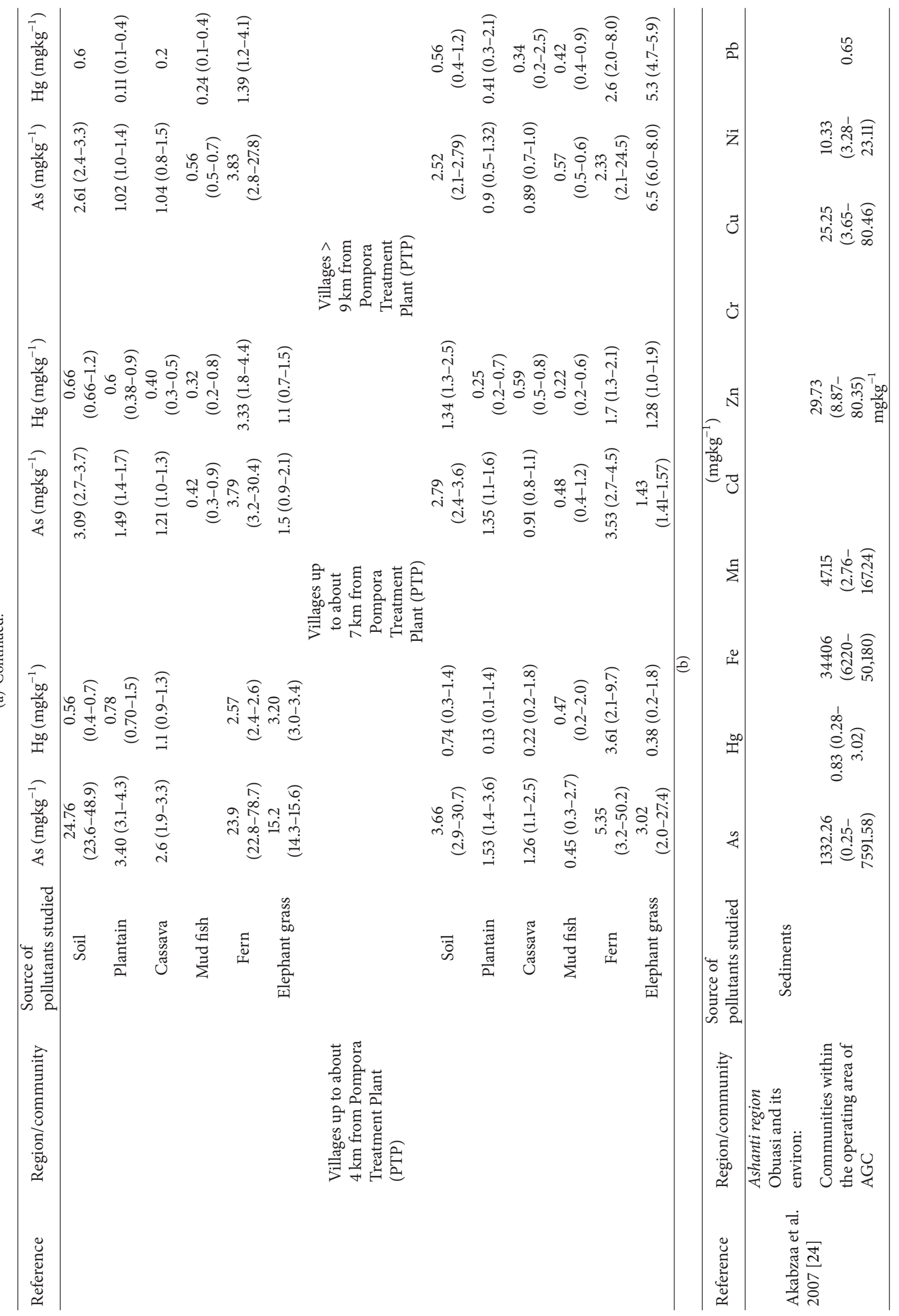




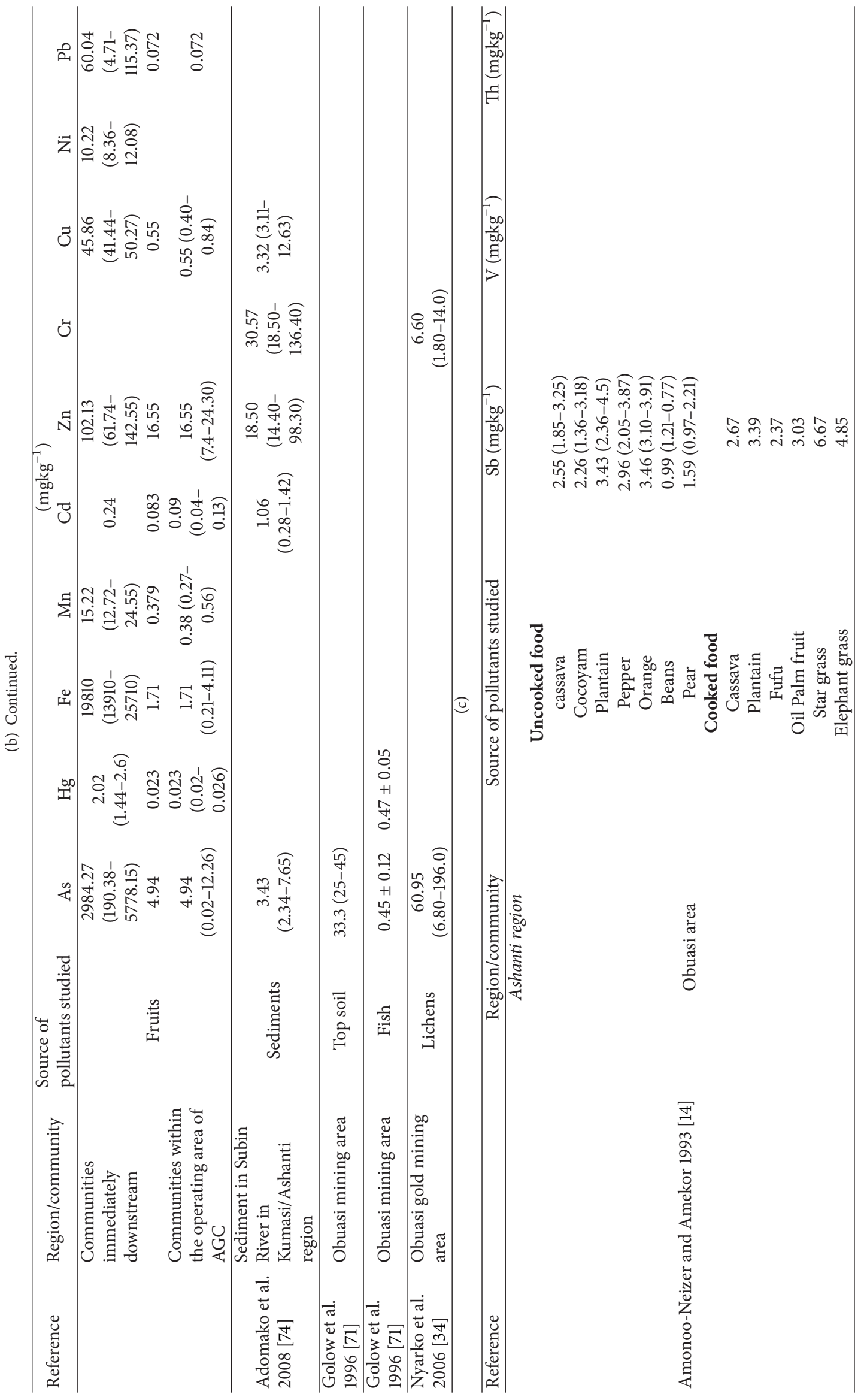




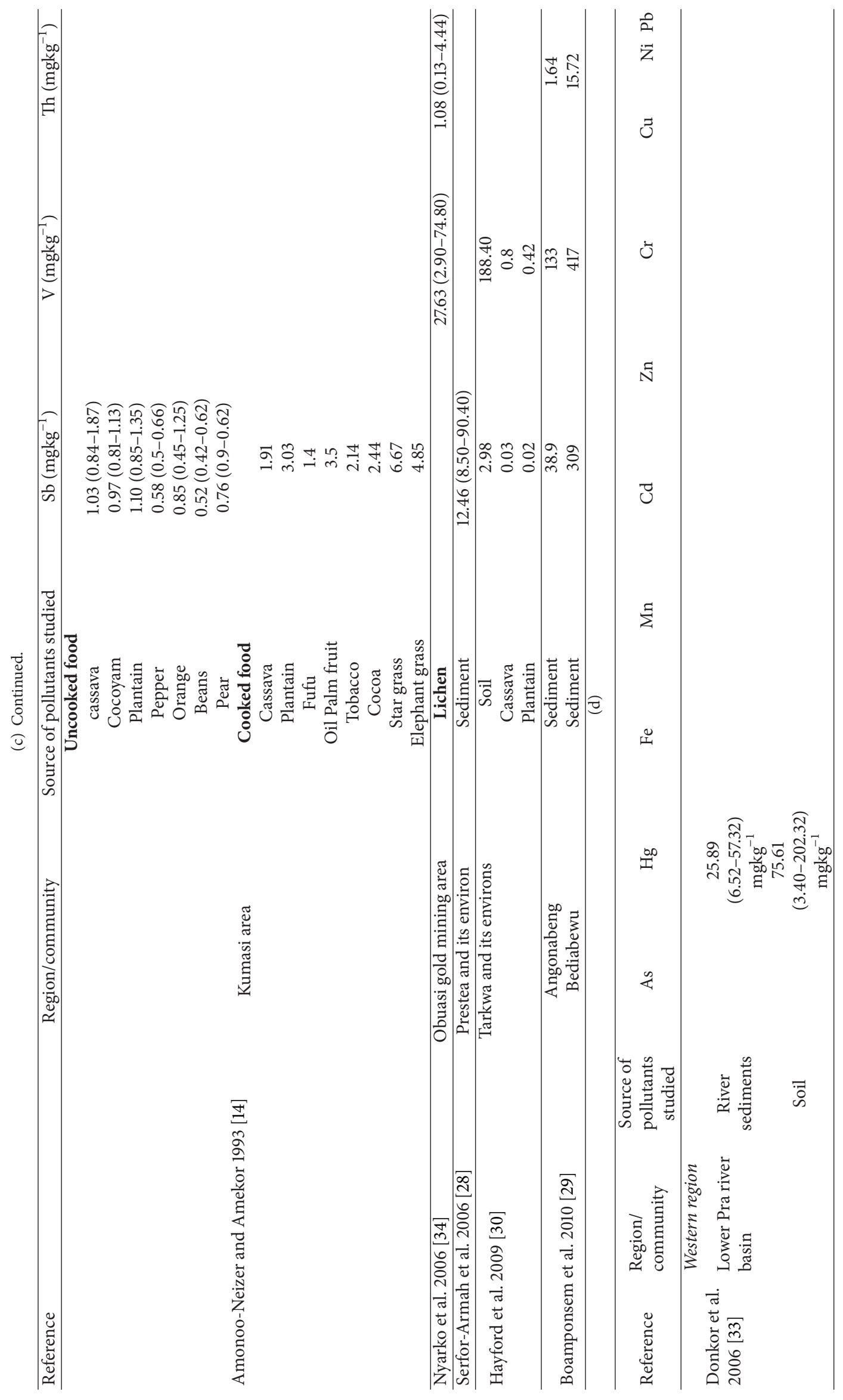




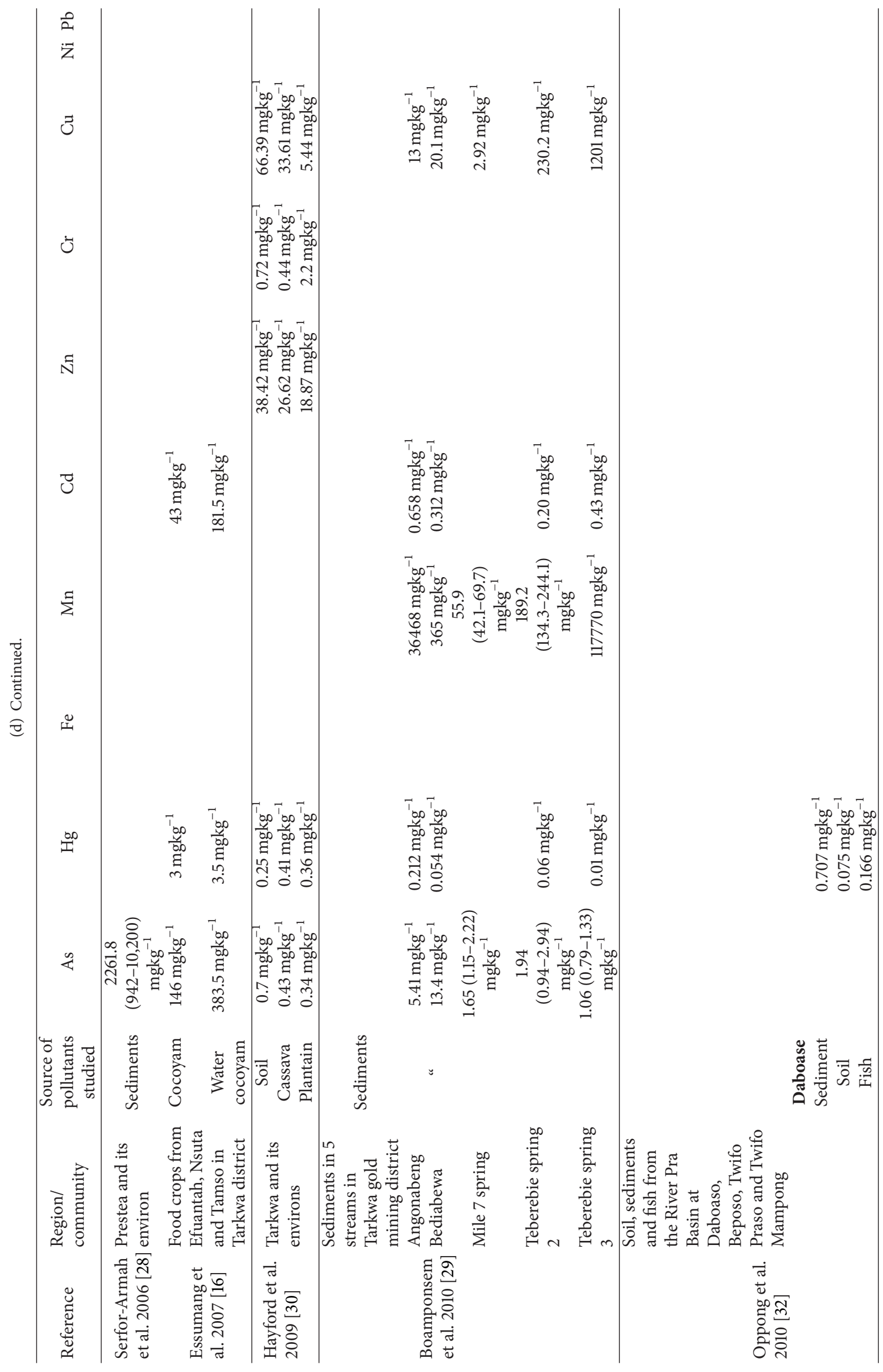




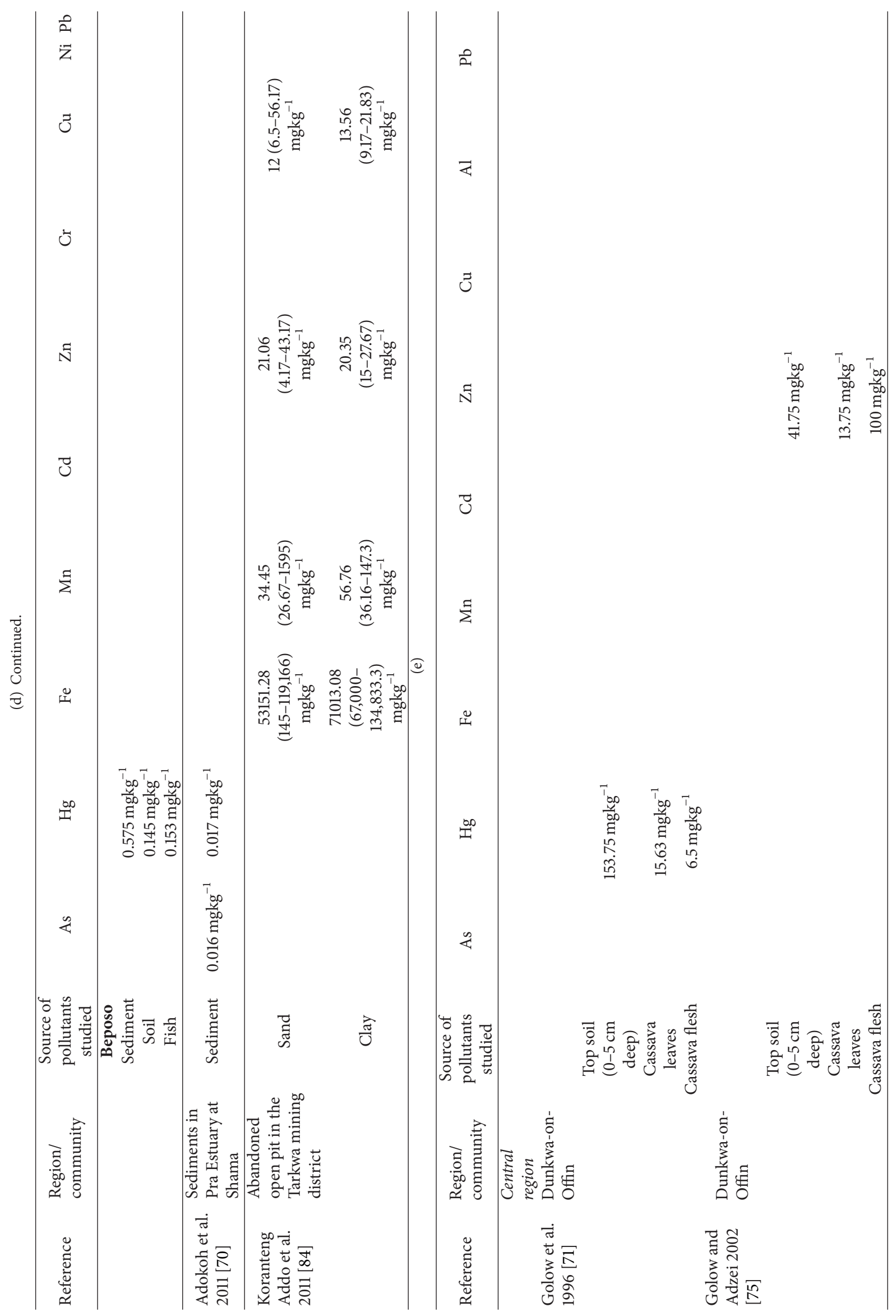




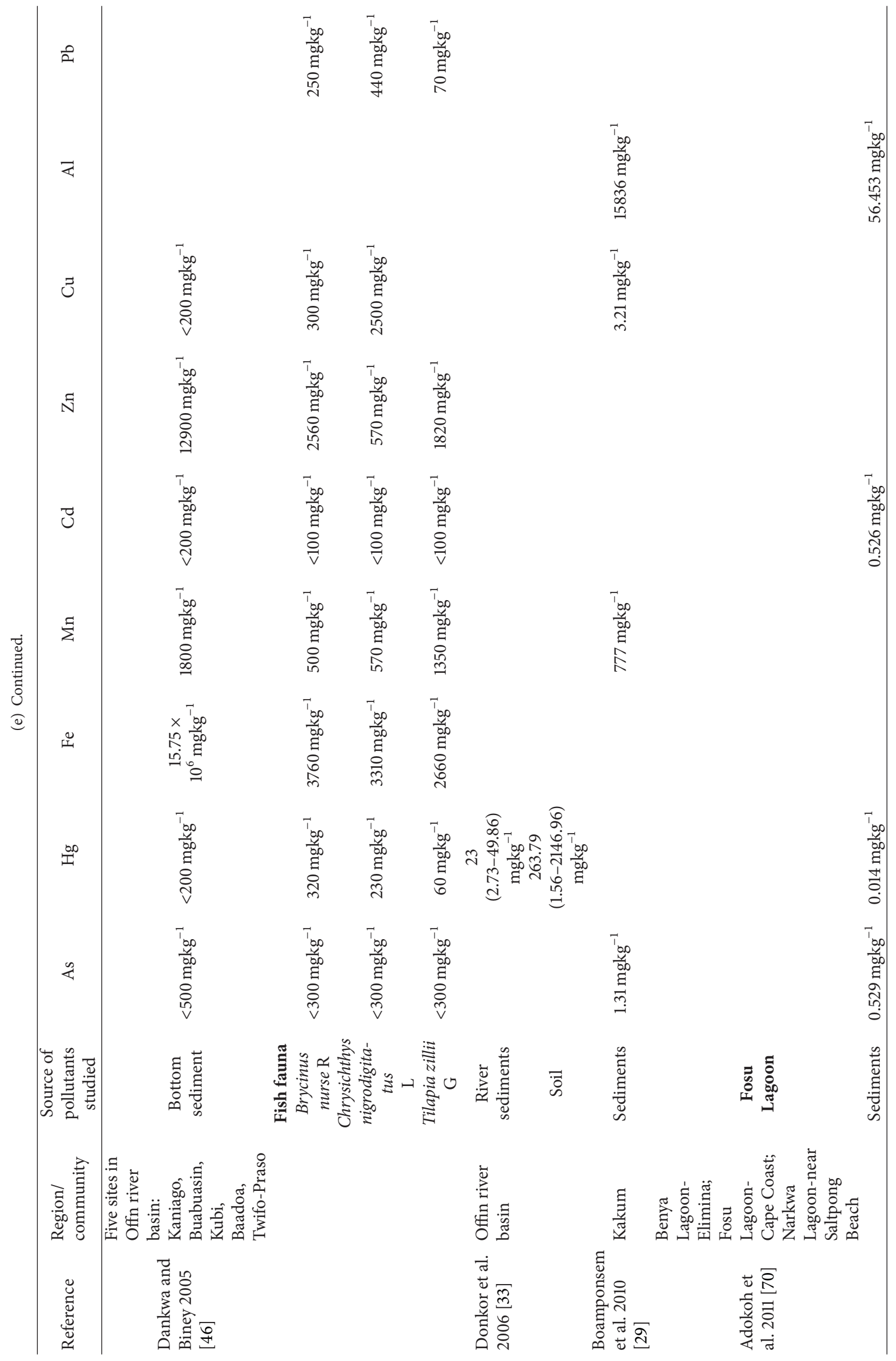




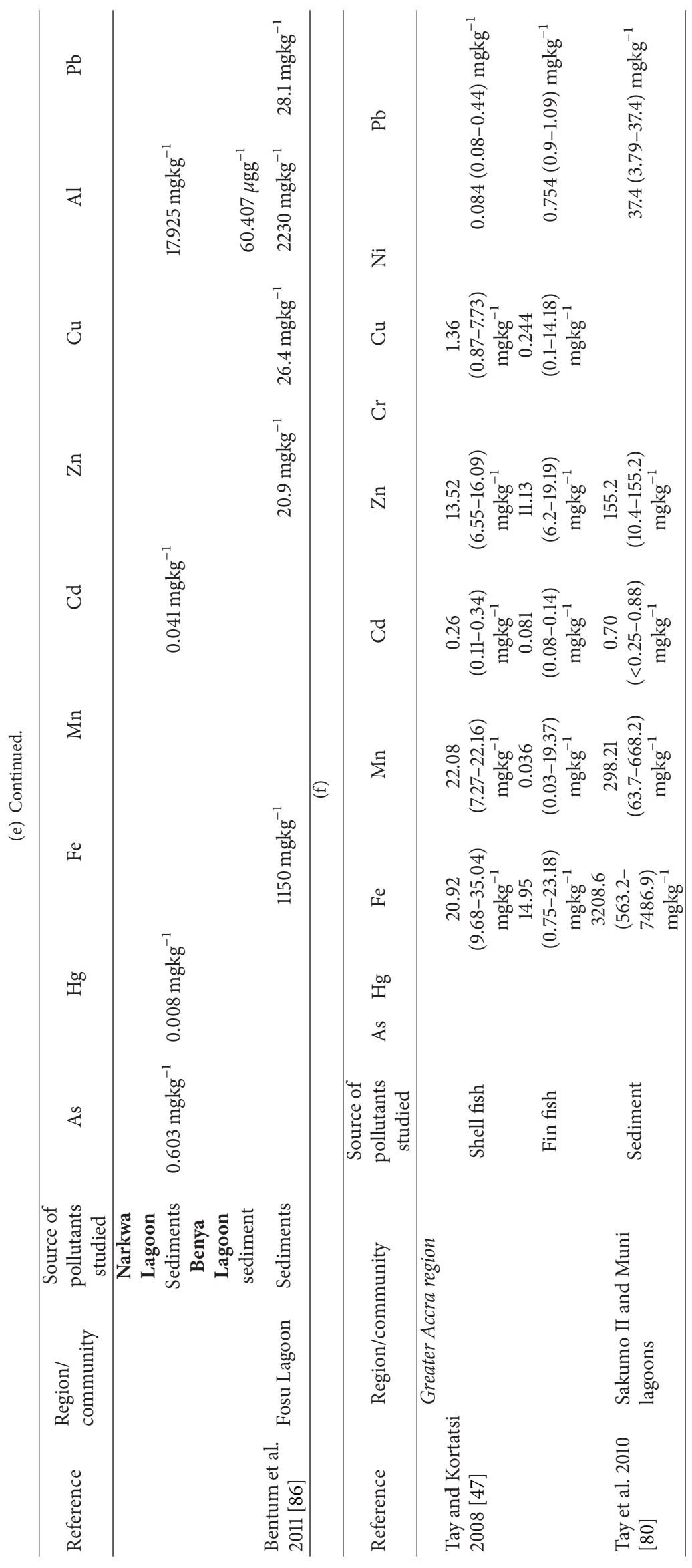


Bogoso. According to Kelly et al. [41], in wells for which the total organic carbon (TOC) concentration is less than $\sim 2$ milligrams per liter $(\mathrm{mg} / \mathrm{L})$, As is usually undetectable $(<1 \mu \mathrm{g} / \mathrm{L})$. For wells with higher TOC values, high As concentrations are more likely. In wells with detectable sulfate, As is almost always undetectable, while wells with undetectable sulfate may have high As concentrations. A likely explanation is that As is associated with iron oxide coatings on sand grains in the aquifer [39]. In areas where organic carbon is abundant, the iron oxide gets reduced and the As is released to the groundwater. In areas with abundant sulfate, sulfate reduction forms ferrous sulfide ( $\mathrm{FeS})$, and the predominant As (V) species are the anions $\mathrm{H}_{2} \mathrm{AsO}_{4}{ }^{-}$and $\mathrm{HAsO}_{4}{ }^{2-}[39,42]$.

Levels of $\mathrm{Cd}$ in groundwater demonstrated that weathering of calcareous rocks was sufficient to provide the amounts of $\mathrm{Cd}$ found in the water profiles. In addition, the input of $\mathrm{Cd}$ by weathering was larger than the input by anthropic or geogenic atmospheric depositions which are the only other potential sources of $\mathrm{Cd}$ in mining areas. Several published studies reviewed reported $\mathrm{Cd}$ in human hair and nails. Cadmium accumulates in the human body adversely affecting a number of organs: liver, kidney, lung, bones, placenta, brain, and the central nervous system [43]. According to Apostoli and Catalani [44], other cadmium-related health effects that have been observed include reproductive, and development toxicity, hepatic, haematological and immunological effects.

According to Morais et al. [36], tobacco smoke is one of the largest single sources of cadmium exposure in humans. Eugenio Figueroa [45] argues that given the fact that the absorption of cadmium from the lungs is much greater than from the gastrointestinal tract, smoking contributes significantly to the total body burden. On the whole, for nonsmokers and non-occupationally exposed workers, food products comprise most of the human exposure burden to cadmium [36]. Some of the published studies reviewed reported $\mathrm{Cd}$ in a variety of food items including fruits [24], cocoyam [16], and shell and fin fish species [46, 47]. In food, only inorganic cadmium salts are present. Organic cadmium compounds are very unstable. Unlike lead and mercury ions, cadmium ions are readily absorbed by plants. They are evenly distributed over the plant. It is widely known that cadmium is taken up through the roots of plants to edible leaves, fruits, and seeds. In fact, during the growth of grains such as wheat and rice, cadmium taken from the soil is concentrated in the core of the kernel [45]. Cadmium also accumulates in animal milk and fatty tissues [45]. Therefore, individuals are exposed to cadmium when eating plant- and animal-based foods. As argued by Castro-González and Méndez-Armenta [43] seafood, such as molluscs and crustaceans, can be also a source of cadmium.

The principal controls on manganese concentration in groundwater are $\mathrm{pH}$ (acidity) and redox (oxidationreduction) condition. Manganese is mobilised under acidic conditions. Hence concentrations can be relatively high in acidic waters such as some industrial waters and those issuing from mines rich in weathered sulphide minerals. This resonates with the situation in the mining areas under study. In pH-neutral conditions, the mobility of manganese is determined by ambient redox conditions. Under anaerobic conditions, manganese is reduced to the more soluble form, $\mathrm{Mn}$ (II), which is released from minerals. As a result, much higher manganese concentrations can be found in anaerobic ground waters.

The highest maximum dissolved $\mathrm{Pb}$ concentrations were found in water samples from surficial aquifer systems, which is not surprising given the highly corrosive conditions (typically low $\mathrm{pH}$, high DOC concentrations, and low dissolved oxygen levels). Lead most likely is transported in ground water by mobile particulate matter [48]. Erel et al. [49] estimate that up to 15 percent of the industrial $\mathrm{Pb}$ deposited from atmospheric deposition is incorporated in water that infiltrates through soils to ground water. Other studies have demonstrated a downward migration of $\mathrm{Pb}$ through soils and into aquifers, which depends on the mobility of organic matter and sesquioxides because of the high stability of $\mathrm{Pb}$-organic matter and $\mathrm{Pb}$-sesquioxide complexes [50]. Any dissolved $\mathrm{Pb}$ that is present (e.g., low $\mathrm{pH}$ waters) in ground water would tend to form complexes with several anionic ligands and the migration of dissolved $\mathrm{Pb}$ in ground water would be dependent on its form (the predominant $\mathrm{Pb}$ species) in solution. For example, free divalent $\mathrm{Pb}$ ion $\left(\mathrm{Pb}^{2+}\right)$, which is the predominant species of $\mathrm{Pb}$ in low-ionic strength waters, tends to sorb on negative sites of clays and other minerals and aquifer materials [51]. Lead concentrations in ground water are related to differences in chemical conditions among aquifers and aquifer systems. In humans, lead ingestion may arise from eating lead contaminated vegetation or animal foods. Another source of ingestion is through the use of leadcontaining vessels or lead-based pottery glazes [36].

It is not always that existence of these metals in humans should be considered as toxic. In higher animals and humans, the proven micronutrients include $\mathrm{Cr}, \mathrm{Cu}, \mathrm{Fe}, \mathrm{Mn}$, and $\mathrm{Zn}$. There is even some evidence that $\mathrm{Cd}, \mathrm{Pb}$, and $\mathrm{Sn}$ may be essential at very low concentrations $[4,52,53]$ although this evidence is disputed by Vieira et al. [54] and Morais et al. [36]. However, the micronutrients which have been conclusively proven to be essential in animal and/or human nutrition and whose concentrations in diets are critical are Co (ruminants only), $\mathrm{Cr}, \mathrm{Cu}, \mathrm{Fe}, \mathrm{Mn}$, and $\mathrm{Zn}$ [4].

Published results on the levels of heavy metals in mine and non-mine workers yielded contradictory results. Mine workers were anticipated to have higher levels of heavy metals than their non-mining counterparts, but published results did not support this expectation. In fact, two of the studies reviewed found evidence to the contrary.

\section{Conclusions}

There is a plethora of environmental issues and concerns on which many scientists have focused their research in past years. In Ghana, tremendous efforts have been mobilized to evaluate the nature, presence, magnitude, fate, and toxicology of anthropogenic-induced heavy metals in diverse environments. The scope of this list is quite broad, encompassing environmental events locally, regionally, and nationally. Heavy metals affect aquatic and terrestrial ecosystems and biotic and abiotic environments and impacts on plants, humans, and wildlife, and virtually all environmental media 
(soil, water, and air). The staggering volume of scientific literature (during the last half century) on heavy metal contamination of environmental media and biota in mining and non-mining environments in Ghana demands remedy by which data can be synthesized. There is thus an urgent need to provide the coherency essential for nonduplicative and current progress in this field which is dynamic and complex. This systematic review attempts to address this need and provides a systematic categorisation of the results of studies published from 1975 to January 2013 on As, Hg, Cd, Zn, Sb, Cr, $\mathrm{Fe}, \mathrm{Co}, \mathrm{Cu}, \mathrm{Ni}, \mathrm{Zn}, \mathrm{Mn}$, and $\mathrm{Pb}$ levels in water, soil, sediment, fruits, and vegetables as well as human hair, urine, blood, and nails in Ghana.

\section{Conflict of Interests}

The authors declare that there is no conflict of interests regarding the publication of this paper.

\section{References}

[1] J. H. Duffus, “"Heavy metals” a meaningless term? (IUPAC Technical Report)," Pure and Applied Chemistry, vol. 74, p. 793, 2009.

[2] D. A. Phipps, "Chemistry and biochemistry of trace metals in biological systems," in Effect of Heavy Metal Pollution on Plants, pp. 1-54, Springer, Amsterdam, The Netherlands, 1981.

[3] G. V. Loon and S. J. Duffy, Environmental Chemistry: A Global Perspective, Oxford University Press, Oxford, UK, 2nd edition, 2005.

[4] B. J. Alloway, Ed., Heavy Metals in Soils: Trace Metals and Metalloids in Soils and Their Bioavailability, Springer, Amsterdam, The Netherlands, 3rd edition, 2013.

[5] F. A. Armah, S. Obiri, D. O. Yawson et al., "Anthropogenic sources and environmentally relevant concentrations of heavy metals in surface water of a mining district in Ghana: a multivariate statistical approach," Journal of Environmental Science and Health A: Toxic/Hazardous Substances and Environmental Engineering, vol. 45, no. 13, pp. 1804-1813, 2010.

[6] C. Filik Iscen, Ö. Emiroglu, S. Ilhan, N. Arslan, V. Yilmaz, and S. Ahiska, "Application of multivariate statistical techniques in the assessment of surface water quality in Uluabat Lake, Turkey," Environmental Monitoring and Assessment, vol. 144, no. 1-3, pp. 269-276, 2008.

[7] S. Obiri, D. K. Dodoo, F. A. Armah, D. K. Essumang, and S. J. Cobbina, "Evaluation of lead and mercury neurotoxic health risk by resident children in the Obuasi municipality, Ghana," Environmental Toxicology and Pharmacology, vol. 29, no. 3, pp. 209-212, 2010.

[8] V. Simeonov, J. A. Stratis, C. Samara et al., "Assessment of the surface water quality in Northern Greece," Water Research, vol. 37, no. 17, pp. 4119-4124, 2003.

[9] F. A. Armah, M. Kuitunen, I. Luginaah, and P. Mkandawire, "Non occupational health risk assessment from exposure to chemical contaminants in the gold mining environment of Tarkwa, Ghana," Trends in Applied Sciences Research, vol. 7, pp. 181-195, 2012.

[10] H. L. Nguyen, M. Leermakers, J. Osán, S. Török, and W. Baeyens, "Heavy metals in Lake Balaton: water column, suspended matter, sediment and biota," Science of the Total Environment, vol. 340, no. 1-3, pp. 213-230, 2005.
[11] S. Shrestha and F. Kazama, "Assessment of surface water quality using multivariate statistical techniques: a case study of the Fuji river basin, Japan," Environmental Modelling and Software, vol. 22, no. 4, pp. 464-475, 2007.

[12] M. Wu and Y. Wang, "Using chemometrics to evaluate anthropogenic effects in Daya Bay, China," Estuarine, Coastal and Shelf Science, vol. 72, no. 4, pp. 732-742, 2007.

[13] R. Naylor, Ghana: An Oxfam Country Profile, Oxfam, Oxford, UK, 2003.

[14] E. H. Amonoo-Neizer and E. M. K. Amekor, "Determination of total arsenic in environmental samples from Kumasi and Obuasi, Ghana," Environmental Health Perspectives, vol. 101, no. 1, pp. 46-49, 1993.

[15] K. A. Asante, T. Agusa, A. Subramanian, O. D. Ansa-Asare, C. A. Biney, and S. Tanabe, "Contamination status of arsenic and other trace elements in drinking water and residents from Tarkwa, a historic mining township in Ghana," Chemosphere, vol. 66, no. 8, pp. 1513-1522, 2007.

[16] D. K. Essumang, D. K. Dodoo, S. Obiri, and J. Y. Yaney, "Arsenic, cadmium, and mercury in Cocoyam (Xanthosoma sagititolium) and Watercocoyam (Colocasia esculenta) in Tarkwa a mining community," Bulletin of Environmental Contamination and Toxicology, vol. 79, no. 4, pp. 377-379, 2007.

[17] S. Obiri, D. K. Dodoo, D. K. Essumang, and F. A. Armah, "Cancer and non-cancer risk assessment from exposure to Arsenic, Copper, and Cadmium in borehole, tap, and surface water in the Obuasi municipality, Ghana," Human and Ecological Risk Assessment, vol. 16, no. 3, pp. 651-665, 2010.

[18] K. B. Pelig-Ba, A. Parker, and M. Price, "Trace element geochemistry from the Birrimian metasediments of the Northern Region of Ghana," Water, Air, and Soil Pollution, vol. 153, no. 1-4, pp. 69-93, 2004.

[19] E. H. Amonoo-Neizer, D. Nyamah, and S. B. Bakiamoh, "Mercury and arsenic pollution in soil and biological samples around the mining town of Obuasi, Ghana," Water, Air, and Soil Pollution, vol. 91, no. 3-4, pp. 363-373, 1996.

[20] M. Babut, R. Sekyi, A. Rambaud et al., "Improving the environmental management of small-scale gold mining in Ghana: a case study of Dumasi," Journal of Cleaner Production, vol. 11, no. 2, pp. 215-221, 2003.

[21] K. B. Pelig-Ba, "Trace elements in groundwater from some crystalline rocks in the upper regions of Ghana," Water, Air, \& Soil Pollution, vol. 103, no. 1-4, pp. 71-89, 1998.

[22] A. Liberati, D. G. Altman, J. Tetzlaff et al., "The PRISMA statement for reporting systematic reviews and meta-analyses of studies that evaluate health care interventions: Explanation and elaboration," Annals of Internal Medicine, vol. 151, no. 4, pp. W-65-W-94, 2009.

[23] V. Simeonov, J. W. Einax, I. Stanimirova, and J. Kraft, "Environmetric modeling and interpretation of river water monitoring data," Analytical and Bioanalytical Chemistry, vol. 374, no. 5, pp. 898-905, 2002.

[24] T. M. Akabzaa, B. K. Banoeng-Yakubo, and J. S. Seyire, "Impact of mining activities on water resources in the vicinity of the Obuasi mine," West African Journal of Applied Ecology, vol. 11, no. 1, 2007.

[25] M. Boadu, E. K. Osae, A. A. Golow, Y. Serfor-Armah, and B. J. B. Nyarko, "Determination of arsenic in some water bodies, untreated ore and tailing samples at Konongo in the Ashanti region of Ghana and its surrounding towns and villages by instrumental neutron activation analysis," Journal of Radioanalytical and Nuclear Chemistry, vol. 249, no. 3, pp. 581-585, 2000. 
[26] C. Tay and F. Momade, "Trace Metal Contamination in Water from Abandoned Mining and Non-Mining areas of the Northern Parts of the Ashanti Gold Belt," West African Journal of Applied Ecology, vol. 10, pp. 187-207, 2006.

[27] K. A. Asante, T. Agusa, A. Subramanian, O. D. Ansa-Asare, C. A. Biney, and S. Tanabe, "Contamination status of arsenic and other trace elements in drinking water and residents from Tarkwa, a historic mining township in Ghana," Chemosphere, vol. 66, no. 8, pp. 1513-1522, 2007.

[28] Y. Serfor-Armah, B. J. B. Nyarko, D. K. Adotey, S. B. Dampare, and D. Adomako, "Levels of arsenic and antimony in water and sediment from Prestea, a gold mining town in Ghana and its environs," Water, Air, and Soil Pollution, vol. 175, no. 1-4, pp. 181$192,2006$.

[29] L. K. Boamponsem, J. I. Adam, S. B. Dampare, B. J. B. Nyarko, and D. K. Essumang, "Assessment of atmospheric heavy metal deposition in the Tarkwa gold mining area of Ghana using epiphytic lichens," Nuclear Instruments and Methods in Physics Research, Section B: Beam Interactions with Materials and Atoms, vol. 268, no. 9, pp. 1492-1501, 2010.

[30] E. K. Hayford, A. Amin, E. K. Osae, and J. Kutu, "Impact of gold mining on soil and some staple foods collected from selected mining communities in and around Tarkwa-Prestea area," West African Journal of Applied Ecology, vol. 14, no. 1, pp. 65-79, 2009.

[31] S. K. Amasa, "Arsenic pollution at Obuasi Goldmine, town, and surrounding countryside," Environmental Health Perspectives, vol. 12, pp. 131-135, 1975.

[32] S. O. B. Oppong, R. B. Voegborlo, S. E. Agorku, and A. A. Adimado, "Total Mercury in fish, sediments and soil from the River Pra Basin, Southwestern Ghana," Bulletin of Environmental Contamination and Toxicology, vol. 85, no. 3, pp. 324-329, 2010.

[33] A. K. Donkor, J. C. Bonzongo, V. K. Nartey, and D. K. Adotey, "Mercury in different environmental compartments of the Pra River Basin, Ghana," Science of the Total Environment, vol. 368, no. 1, pp. 164-176, 2006.

[34] B. J. B. Nyarko, Y. Serfor-Armah, E. H. K. Akaho, D. Adomako, and S. Osae, "Determination of heavy metal pollution levels in lichens at Obuasi gold mining area in Ghana," Journal of Applied Science and Technology, vol. 9, no. 1, pp. 28-33, 2006.

[35] A. A. Adimado and D. A. Baah, "Mercury in human blood, urine, hair, nail, and fish from the Ankobra and Tano river basins in Southwestern Ghana," Bulletin of Environmental Contamination and Toxicology, vol. 68, no. 3, pp. 339-346, 2002.

[36] S. Morais, F. G. Costa, and M. L. Pereira, "Heavy metals and human health," in Environmental Health, J. Oosthuizen, Ed., pp. 227-246, InTech, 1st edition, 2012.

[37] M. A. Rauf and A. Hanan, "Quality assurance considerations in chemical analysis," Quality Assurance Journal, vol. 12, no. 1, pp. 16-21, 2009.

[38] W. Baeyens, M. Elskens, G. Gillain, and L. Goeyens, "Biogeochemical behaviour of $\mathrm{Cd}, \mathrm{Cu}, \mathrm{Pb}$ and $\mathrm{Zn}$ in the Scheldt estuary during the period 1981-1983," Hydrobiologia, vol. 366, no. 1-3, pp. 15-44, 1997.

[39] T. R. Holm, W. R. Kelly, S. D. Wilson, and J. L. Talbott, "Arsenic removal at Illinois iron removal plants," The American Water Works Association Journal, vol. 100, no. 9, pp. 139-150, 2008.

[40] G. Foli and P. M. Nude, "Concentration levels of some inorganic contaminants in streams and sediments in areas of pyrometallurgical and hydrometallurgical activities at the Obuasi gold mine, Ghana," Environmental Earth Sciences, vol. 65, no. 3, pp. 753-763, 2012.
[41] W. R. Kelly, T. R. Holm, S. D. Wilson, and G. S. Roadcap, "Arsenic in glacial aquifers: sources and geochemical controls," Ground Water, vol. 43, no. 4, pp. 500-510, 2005.

[42] G. Samanta and D. A. Clifford, "Preservation of inorganic arsenic species in groundwater," Environmental Science \& Technology, vol. 39, no. 22, pp. 8877-8882, 2005.

[43] M. I. Castro-González and M. Méndez-Armenta, "Heavy metals: implications associated to fish consumption," Environmental Toxicology and Pharmacology, vol. 26, pp. 263-271, 2008.

[44] P. Apostoli and S. Catalani, "Metal ions affecting reproduction and development," Metal Ions in Life Sciences, vol. 8, pp. 263303, 2011.

[45] B. Eugenio Figueroa, "Are more restrictive food cadmium standards justifiable health safety measures or opportunistic barriers to trade? An answer from economics and public health," The Science of the Total Environment, vol. 389, no. 1, pp. $1-9,2008$.

[46] H. R. Dankwa and C. A. Biney, "Impact of mining operations on the ecology of river Offin in Ghana," West African Journal of Applied Ecology, vol. 7, no. 1, 2005.

[47] C. Tay and B. Kortatsi, "Groundwater quality studies: a case study of the Densu Basin, Ghana," West African Journal of Applied Ecology, vol. 12, no. 1, 2008.

[48] Y. Erel and C. C. Patterson, "Leakage of industrial lead into the hydrocycle," Geochimica et Cosmochimica Acta, vol. 58, no. 15, pp. 3289-3296, 1994.

[49] Y. Erel, A. Veron, and L. Halicz, "Tracing the transport of anthropogenic lead in the atmosphere and in soils using isotopic ratios," Geochimica et Cosmochimica Acta, vol. 61, no. 21, pp. 4495-4505, 1997.

[50] Y. Erel and J. J. Morgan, "The relationships between rockderived lead and iron in natural waters," Geochimica et Cosmochimica Acta, vol. 56, no. 12, pp. 4157-4167, 1992.

[51] O. M. Sæther, B. Bølviken, J. Låg, and E. Steinnes, "Concentration and chemical form of lead during natural transportation in groundwater," Chemical Geology, vol. 69, no. 3-4, pp. 309-319, 1988.

[52] R. D. Graham, "Micronutrient deficiencies in crops and their global significance," in Micronutrient Deficiencies in Global Crop Production, B. J. Alloway, Ed., chapter 2, pp. 41-61, Springer, Dordrecht, The Netherlands, 2008.

[53] R. M. Welch, "Linkages between essential trace elements in food crops and human health," in Micronutrient Deficiencies in Global Crop Production, B. J. Alloway, Ed., vol. 12, chapter 12, pp. 287309, Springer, Dordrecht, The Netherlands, 2007.

[54] C. Vieira, S. Morais, S. Ramos, C. Delerue-Matos, and M. B. P. P. Oliveira, "Mercury, cadmium, lead and arsenic levels in three pelagic fish species from the Atlantic Ocean: intra- and interspecific variability and human health risks for consumption," Food and Chemical Toxicology, vol. 49, no. 4, pp. 923-932, 2011.

[55] D. K. Essumang, "Analysis and human health risk assessment of arsenic, cadmium, and mercury in Manta birostris (manta ray) caught along the Ghanaian coastline," Human and Ecological Risk Assessment, vol. 15, no. 5, pp. 985-998, 2009.

[56] Y. Paruchuri, A. Siuniak, N. Johnson et al., "Occupational and environmental mercury exposure among small-scale gold miners in the Talensi-Nabdam District of Ghana's Upper East region," Science of the Total Environment, vol. 408, no. 24, pp. 6079-6085, 2010.

[57] N. Basu, D.-H. Nam, E. Kwansaa-Ansah, E. P. Renne, and J. O. Nriagu, "Multiple metals exposure in a small-scale artisanal 
gold mining community," Environmental Research, vol. 111, no. 3, pp. 463-467, 2011.

[58] R. G. Abrefah, D. K. Adotey, E. Ampomah-Amoako, and N. S. Opata, "Biomonitoring of occupational exposure to total arsenic and total mercury in urine of goldmine workers in Southwestern Ghana," Environmental Research, Engineering and Management, vol. 56, no. 2, pp. 43-48, 2011.

[59] K. A. Asante, T. Agusa, C. A. Biney et al., "Multi-trace element levels and arsenic speciation in urine of e-waste recycling workers from Agbogbloshie, Accra in Ghana," Science of the Total Environment, vol. 424, pp. 63-73, 2012.

[60] E. E. Kwaansa-Ansah, N. Basu, and J. O. Nriagu, "Environmental and occupational exposures to mercury among indigenous people in Dunkwa-On-Offin, a small scale gold mining area in the south-west of Ghana," Bulletin of Environmental Contamination and Toxicology, vol. 85, no. 5, pp. 476-480, 2010.

[61] J. R. Fianko, S. Osae, D. Adomako, D. K. Adotey, and Y. Serfor-Armah, "Assessment of heavy metal pollution of the Iture Estuary in the central region of Ghana," Environmental Monitoring and Assessment, vol. 131, no. 1-3, pp. 467-473, 2007.

[62] P. L. Smedley, "Arsenic in rural groundwater in Ghana," Journal of African Earth Sciences, vol. 22, no. 4, pp. 459-470, 1996.

[63] C. G. Amedjoe, G. Foli, and P. M. Nude, "Geological and geochemical controls on the composition of natural drainages in homase mineral deposit environment," Research Journal of Environmental and Earth Sciences, vol. 4, no. 3, pp. 255-263, 2012.

[64] S. Obiri, "Determination of heavy metals in water from boreholes in dumasi in the Wassa West District of western region of Republic of Ghana," Environmental Monitoring and Assessment, vol. 130, no. 1-3, pp. 455-463, 2007.

[65] F. A. Armah, J. O. Odoi, E. K. A. Afrifa, A. N. M. Pappoe, D. O. Yawson, and P. K. Essandoh, "Spatial variability of trace metals in surface and groundwater within a Contaminated Mining Environment in Ghana," Research Journal of Environmental and Earth Sciences, vol. 3, no. 5, pp. 546-554, 2011.

[66] B. K. Kortatsi, C. K. Tay, G. Anornu, E. Hayford, and G. A. Dartey, "Hydrogeochemical evaluation of groundwater in the lower Offin basin, Ghana," Environmental Geology, vol. 53, no. 8, pp. 1651-1662, 2008.

[67] C. K. Tay, "Chemical characteristics of groundwater in the Akatsi and Ketu Districts of the Volta Region, Ghana," West African Journal of Applied Ecology, vol. 11, no. 1, pp. 1-23, 2007.

[68] Y. Serfor-Armah, B. J. B. Nyarko, E. K. Osae, D. Carboo, S. Anim-Sampong, and F. Seku, "Rhodophyta seaweed species as bioindicators for monitoring toxic element pollutants in the marine ecosystem of Ghana," Water, Air, and Soil Pollution, vol. 127, no. 1-4, pp. 243-253, 2001.

[69] H. M. A. Rossiter, P. A. Owusu, E. Awuah, A. M. MacDonald, and A. I. Schäfer, "Chemical drinking water quality in Ghana: Water costs and scope for advanced treatment," Science of the Total Environment, vol. 408, no. 11, pp. 2378-2386, 2010.

[70] C. K. Adokoh, E. A. Obodai, D. K. Essumang, Y. Serfor-Armah, B. J. B. Nyarko, and A. Asabere-Ameyaw, "Statistical evaluation of environmental contamination, distribution and source assessment of heavy metals (Aluminum, Arsenic, Cadmium, and Mercury) in some lagoons and an estuary along the coastal belt of Ghana," Archives of Environmental Contamination and Toxicology, vol. 61, no. 3, pp. 389-400, 2011.

[71] A. A. Golow, A. Schlueter, S. Amihere-Mensah, H. L. K. Granson, and M. S. Tetteh, "Distribution of arsenic and sulphate in the vicinity of Ashanti goldmine at Obuasi, Ghana," Bulletin of Environmental Contamination and Toxicology, vol. 56, no. 5, pp. 703-710, 1996.

[72] S. Obiri, D. K. Dodoo, F. Okai-Sam, D. K. Essumang, and A. Adjorlolo-Gasokpoh, "Cancer and non-cancer health risk from eating cassava grown in some mining communities in Ghana," Environmental Monitoring and Assessment, vol. 118, no. 1-3, pp. 37-49, 2006.

[73] E. E. Adomako, P. N. Williams, C. Deacon, and A. A. Meharg, "Inorganic arsenic and trace elements in Ghanaian grain staples," Environmental Pollution, vol. 159, no. 10, pp. 2435-2442, 2011.

[74] D. Adomako, B. J. B. Nyarko, S. B. Dampare et al., "Determination of toxic elements in waters and sediments from River Subin in the Ashanti region of Ghana," Environmental Monitoring and Assessment, vol. 141, no. 1-3, pp. 165-175, 2008.

[75] A. A. Golow and E. A. Adzei, "Mercury in surface soil and cassava crop near an alluvial goldmine at Dunkwa-on-Offin, Ghana," Bulletin of Environmental Contamination and Toxicology, vol. 69, no. 2, pp. 228-235, 2002.

[76] S. M. Yidana, D. Ophori, and B. Banoeng-Yakubo, "A multivariate statistical analysis of surface water chemistry data-The Ankobra Basin, Ghana," Journal of Environmental Management, vol. 86, no. 1, pp. 80-87, 2008.

[77] J. K. Bentum, O. J. Sackitey, J. K. Tuffuor, D. K. Essumang, E. J. Koranteng-Addo, and E. Owusu-Ansah, "Lead, Cadmium and Arsenic in breast milk of lactating mothers in OdumanseAtua community in Manya Krobo district of eastern region of Ghana," Journal of Chemical and Pharmaceutical Research, vol. 2, pp. 16-20, 2010.

[78] B. Kumi-Boateng, Assessing the Spatial Distribution of Arsenic Concentration from Goldmine for Environmental Management at Obuasi, Ghana, International Institute for Geoinformation Sciences and Earth Observation, Enschede, The Netherlands, 2007.

[79] A. Y. Karikari and O. D. Ansa-Asare, "Physico-chemical and microbial water quality assessment of Densu River of Ghana," West African Journal of Applied Ecology, vol. 10, no. 1, 2006.

[80] C. K. Tay, R. Asmah, and C. A. Biney, "Trace metal levels in water and sediment from the Sakumo II and Muni Lagoons, Ghana," West African Journal of Applied Ecology, vol. 16, no. 1, 2010.

[81] B. K. Kortatsi, "Hydrochemical framework of groundwater in the Ankobra Basin, Ghana," Aquatic Geochemistry, vol. 13, no. 1, pp. 41-74, 2007.

[82] S. Dapaah-Siakwan and P. Gyau-Boakye, "Hydrogeologic framework and borehole yields in Ghana," Hydrogeology Journal, vol. 8, no. 4, pp. 405-416, 2000.

[83] V. K. Nartey, R. K. Adaboh, J. R. Fianko, and A. Donkor, "Water quality assessment of streams draining the Akwapim Ridge of Ghana," West African Journal of Applied Ecology, vol. 8, no. 1, 2005.

[84] E. J. Koranteng Addo, E. Owusu Ansah, L. K. Boamponsem, J. K. Bentum, and S. Arthur, "Levels of zinc, copper, iron and manganese in soils of abandoned mine pits around the Tarkwa gold mining area of Ghana," Advances in Applied Science Research, vol. 2, no. 1, 2011.

[85] O. D. Ansa-Asare and K. A. Asante, "The water quality of the Birim River in South-East Ghana," West African Journal of Applied Ecology, vol. 1, pp. 23-34, 2000.

[86] J. K. Bentum, M. Anang, K. O. Boadu, E. J. Koranteng-Addo, and E. O. Antwi, "Assessment of heavy metals pollution of sediments 
from Fosu lagoon in Ghana," Bulletin of the Chemical Society of Ethiopia, vol. 25, no. 2, pp. 191-196, 2011.

[87] C. Tay, R. Asmah, and C. A. Biney, "Trace metal concentrations in commercially important fishes from some coastal and inland waters in Ghana," West African Journal of Applied Ecology, vol. 13, no. 1, pp. 27-38, 2008.

[88] B. K. Kortatsi, "Hydrochemical characterization of groundwater in the Accra plains of Ghana," Environmental Geology, vol. 50, no. 3, pp. 299-311, 2006. 

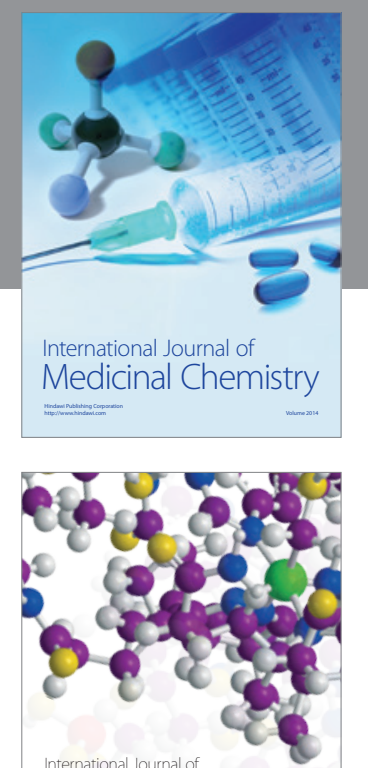

\section{Carbohydrate} Chemistry

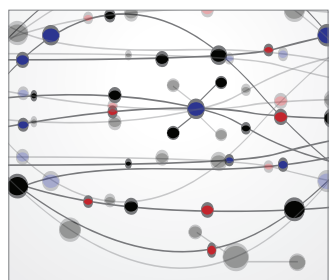

The Scientific World Journal
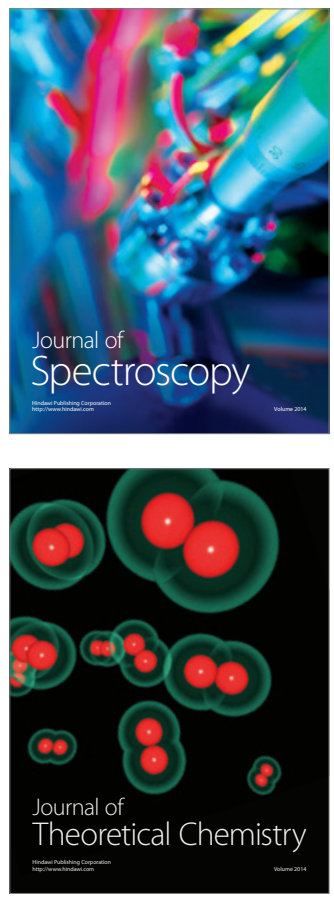
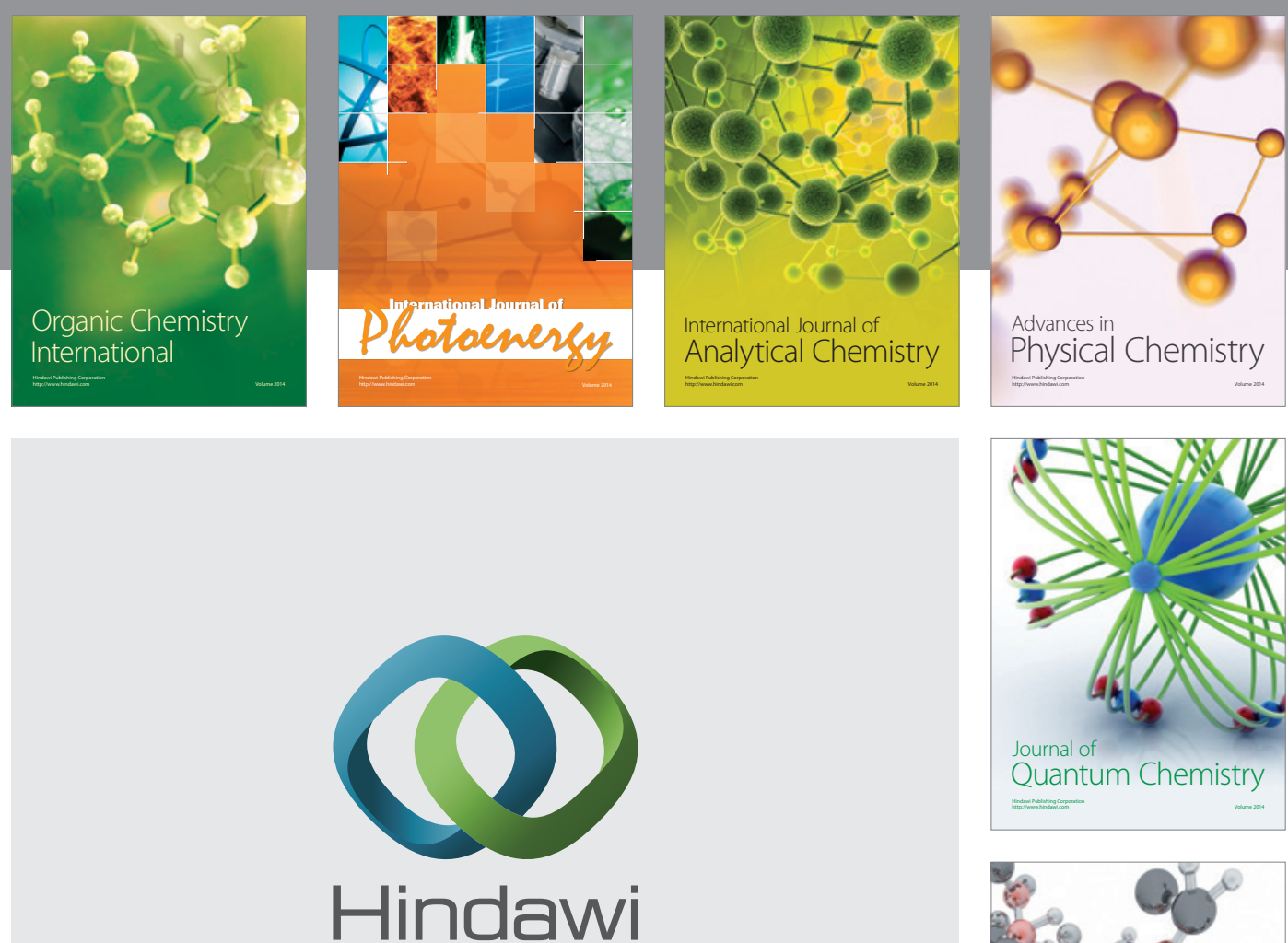

Submit your manuscripts at

http://www.hindawi.com

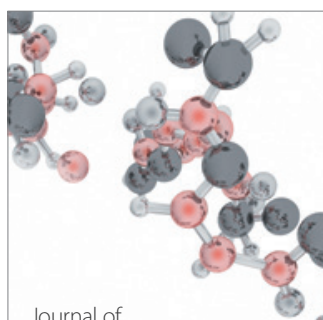

Analytical Methods

in Chemistry

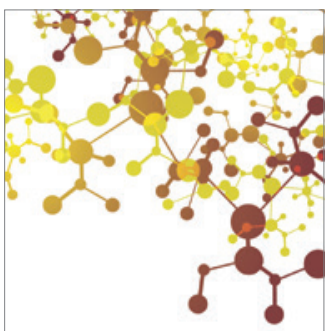

Journal of

Applied Chemistry

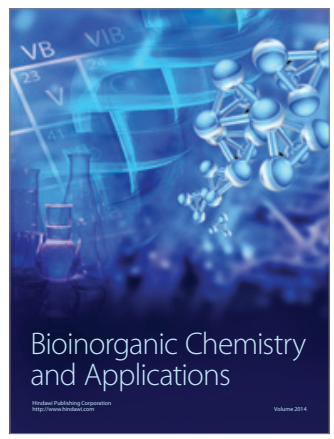

Inorganic Chemistry
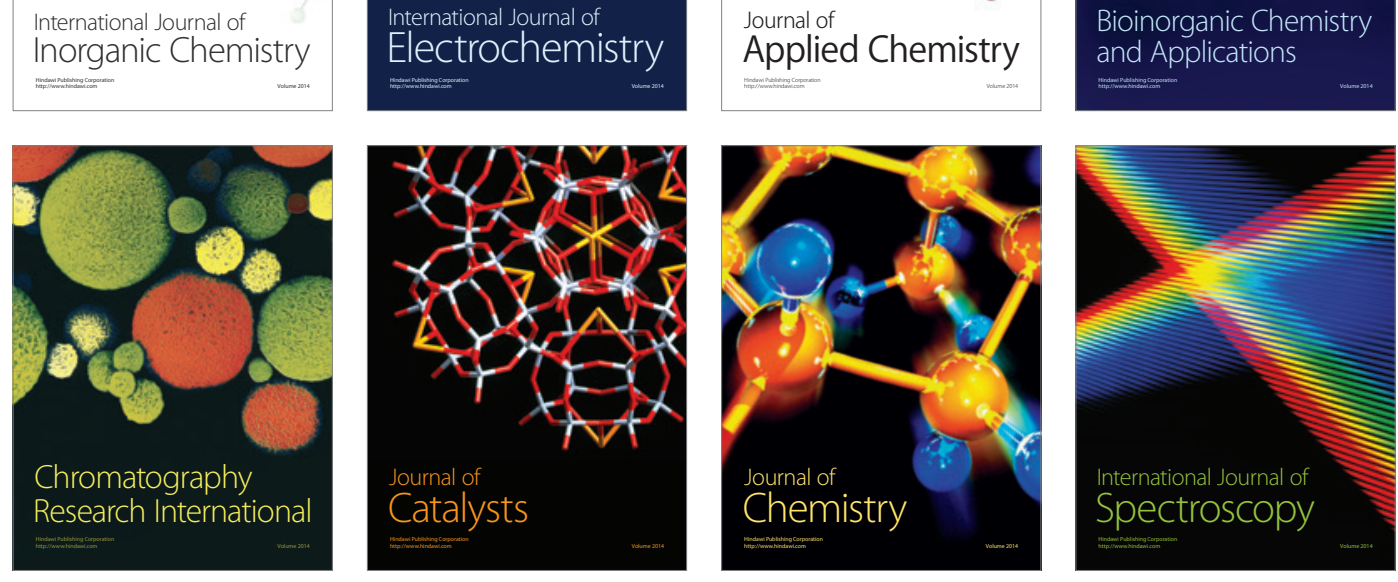